\title{
Iron and silicon isotope behaviour accompanying weathering in Icelandic soils, and the implications for iron export from peatlands
}

\author{
S. Opfergelt ${ }^{\mathrm{a}, \mathrm{b}, *}$, H.M. Williams ${ }^{\mathrm{b}, \mathrm{c}}$, J.T. Cornelis ${ }^{\mathrm{a}, \mathrm{d}}$, R.A. Guicharnaud ${ }^{\mathrm{e}, \mathrm{f}}$, \\ R.B. Georg ${ }^{\text {b,g }}$, C. Siebert ${ }^{\text {b,h }}$, S.R. Gislason ${ }^{\mathrm{e}}$, A.N. Halliday ${ }^{\mathrm{b}}$, K.W. Burton ${ }^{\mathrm{b}, \mathrm{c}}$ \\ ${ }^{a}$ Earth and Life Institute, Université catholique de Louvain, Croix du Sud bte L7.05.10, 1348 Louvain-la-Neuve, Belgium \\ ${ }^{\mathrm{b}}$ Department of Earth Sciences, University of Oxford, South Parks Road, Oxford OX1 3AN, United Kingdom \\ ${ }^{\mathrm{c}}$ Department of Earth Sciences, Durham University, DH1 3LE Durham, United Kingdom \\ ${ }^{\mathrm{d}}$ Gembloux AgroBio-Tech, Université de Liège, Av. Maréchal Juin 27, 5030 Gembloux, Belgium \\ ${ }^{\mathrm{e}}$ Institute of Earth Sciences, University of Iceland, Sturlugata 7, 101 Reykjavik, Iceland \\ ${ }_{\mathrm{f}}^{\mathrm{f}}$ European Commission, Land Resource Management Unit, 21027 Ispra, Italy \\ ${ }^{\mathrm{g}}$ Trent University, Water Quality Centre, 1600 West Bank Dr., Peterborough, Ontario, Canada \\ ${ }^{\mathrm{h}}$ Geomar, Helmholtz Center for Ocean Research, Wischhofstrasse 1-3, 24146 Kiel, Germany
}

Received 15 January 2016; accepted in revised form 23 August 2017; Available online 1 September 2017

\begin{abstract}
Incipient warming of peatlands at high latitudes is expected to modify soil drainage and hence the redox conditions, which has implications for Fe export from soils. This study uses Fe isotopes to assess the processes controlling Fe export in a range of Icelandic soils including peat soils derived from the same parent basalt, where Fe isotope variations principally reflect differences in weathering and drainage. In poorly weathered, well-drained soils (non-peat soils), the limited Fe isotope fractionation in soil solutions relative to the bulk soil $\left(\Delta^{57} \mathrm{Fe}_{\text {solution-soil }}=-0.11 \pm 0.12 \%\right.$ ) is attributed to proton-promoted mineral dissolution. In the more weathered poorly drained soils (peat soils), the soil solutions are usually lighter than the bulk soil $\left(\Delta^{57} \mathrm{Fe}_{\text {solution-soil }}=\right.$ $-0.41 \pm 0.32 \%$ ) , which indicates that Fe has been mobilised by reductive mineral dissolution and/or ligand-controlled dissolution. The results highlight the presence of Fe-organic complexes in solution in anoxic conditions. An additional constraint on soil weathering is provided by $\mathrm{Si}$ isotopes. The $\mathrm{Si}$ isotope composition of the soil solutions relative to the soil $\left(\Delta^{30} \mathrm{Si}_{\text {solution-soil }}=0.92\right.$ $\pm 0.26 \%$ ) generally reflects the incorporation of light $\mathrm{Si}$ isotopes in secondary aluminosilicates. Under anoxic conditions in peat soils, the largest $\mathrm{Si}$ isotope fractionation in soil solutions relative to the bulk soil is observed $\left(\Delta^{30} \mathrm{Si}_{\text {solution-soil }}=1.63 \pm 0.40 \%\right.$ and attributed to the cumulative contribution of secondary clay minerals and amorphous silica precipitation. Si supersaturation in solution with respect to amorphous silica is reached upon freezing when Al availability to form aluminosilicates is limited by the affinity of $\mathrm{Al}$ for metal-organic complexes. Therefore, the precipitation of amorphous silica in peat soils indirectly supports the formation of metal-organic complexes in poorly drained soils. These observations highlight that in a scenario of decreasing soil drainage with warming high latitude peatlands, Fe export from soils as Fe-organic complexes will increase, which in turn has implications for Fe transport in rivers, and ultimately the delivery of Fe to the oceans.
\end{abstract}

(C) 2017 Elsevier Ltd. All rights reserved.

Keywords: Basalt weathering; Volcanic soil; Iceland; Fe isotopes; Si isotopes; Fe export; Peat soil

\footnotetext{
* Corresponding author at: UCL/ELIE, Croix du Sud 2 bte L7.05.10, 1348 Louvain-la-Neuve, Belgium. Fax: +32 10474525.

E-mail address: sophie.opfergelt@uclouvain.be (S. Opfergelt).
} 


\section{INTRODUCTION}

Iron in rivers ultimately originates from mineral weathering and export from soils. Rivers are a major source of $\mathrm{Fe}$ to the ocean, and $\mathrm{Fe}$ is an essential nutrient for marine primary production (Martin and Fitzwater, 1988; Morel et al., 1991; Boyd et al., 2000; Poulton and Raiswell 2002; Smetacek et al., 2012). Recent evidence suggests that peatlands play a pivotal role in the delivery of Fe to coastal waters, and the organic acids that originate in peat likely serve as the principal metal chelator for Fe transport in rivers (Krachler et al., 2005, 2010). The transport of Fe in these colloidal $(<10 \mathrm{kD})$ metal-organic complexes is considered a major way for peat-derived riverine Fe to escape $\mathrm{Fe}$ oxyhydroxide precipitation and flocculation, and hence escape estuarine removal (Boyle and Edmond, 1977; Krachler et al., 2005, 2010).

High latitude permafrost peatlands currently face dramatic changes in temperature (Hecht et al., 2007; Westermann et al., 2015), and the predicted $37 \%$ reduction of the permafrost extent by 2100 (IPCC 2013) is likely to result in significant changes in soil drainage. Although whether permafrost peatlands will become wetter or drier is still uncertain (e.g., Swindles et al., 2015). Changing freeze-thaw cycles and frequencies of seasonal anoxic soils is likely to impact redox-controlled process such as $\mathrm{Fe}$ mobilisation, and hence, $\mathrm{Fe}$ export from soils. In order to better predict the potential impact of warming peatlands at high latitudes on the $\mathrm{Fe}$ export from soils in these regions, a detailed understanding of processes controlling Fe behaviour in high latitude soils is required.

In soils, $\mathrm{Fe}$ is initially locked up in primary minerals. Through chemical weathering, $\mathrm{Fe}$ is mobilised by protonpromoted, ligand-controlled or reductive dissolution (e.g., Cornell and Schwertmann, 2003; Bonneville et al., 2004; Wiederhold et al., 2006; Melton et al., 2014). This mobilised Fe can reside in soils as secondary phyllosilicates, Fe oxyhydroxides and/or chelated as metal-organic complexes (e.g., Cornell and Schwertmann, 2003; Thompson et al., 2011), or be exported from soils. The evolution of Fe in secondary phases is a function of (i) soil drainage that affects redox processes, (ii) soil weathering degree that affects the mineral reserve and the solubility of minerals, and (iii) soil organic matter content that affects the amount and type of organic ligands (e.g., Schwertmann, 2008; Fritsch et al., 2009).

The stable iron isotope compositions of soils can be shifted from the composition of the parent material by the removal or addition of significant pools of fractionated $\mathrm{Fe}$, providing a valuable approach to trace the processes controlling $\mathrm{Fe}$ mobilisation and export from soils (e.g., Fantle and DePaolo, 2004; Emmanuel et al., 2005; Thompson et al., 2007; Wiederhold et al., 2007a; Mansfeldt et al., 2012; Fekiacova et al., 2013; Liu et al., 2014; Schulz et al., 2016; Dauphas et al., 2017). More precisely, $\mathrm{Fe}$ isotopes in soils are sensitive to redox processes, to weathering processes and the formation of Fe-oxides, and to the formation of Fe-organic complexes. Light Fe isotopes are often enriched in soils containing secondary $\mathrm{Fe}$ phases (e.g., Wiederhold et al., 2007b; Poitrasson et al., 2008; Guelke et al., 2010; Kiczka et al., 2011; Yesavage et al., 2012; Liu et al., 2014; Fekiacova et al., 2017). This enrichment can be explained by the quantitative precipitation of light $\mathrm{Fe}$-oxyhydroxides from light $\mathrm{Fe}$ isotopes preferentially released by proton-promoted mineral weathering (Chapman et al., 2009; Kiczka et al., 2010a), reductive mineral dissolution (e.g., Wiederhold et al., 2006, 2007a, 2007b), and ligand-controlled mineral dissolution (Brantley et al., 2001, 2004; Wiederhold et al., 2006, 2007b; Buss et al., 2010). In solution, there is an isotope fractionation between $\mathrm{Fe}(\mathrm{III})$ and $\mathrm{Fe}(\mathrm{II})$, with light isotopes accumulating in the Fe(II) (Johnson et al., 2002; Welch et al., 2003; Thompson et al., 2007; Wiederhold et al., 2007a; Wu et al., 2011). The greater mobility of Fe(II) is a cause of soil $\mathrm{Fe}$ isotope fractionation in anoxic soils, leaving a residual soil enriched in heavy $\mathrm{Fe}$ (e.g., Wiederhold et al., 2007a; Fekiacova et al., 2013; Akerman et al., 2014; Schuth et al., 2015). In the presence of organic ligands, heavy $\mathrm{Fe}$ isotopes are favoured in Fe-organic complexes relative to uncomplexed $\mathrm{Fe}$ in solution (Dideriksen et al., 2008; Morgan et al., 2010), potentially modifying the Fe isotope fractionation induced by mineral dissolution.

Icelandic soils hosts high latitude soils, that range from poorly weathered, well drained, oxic soils to more intensely weathered, poorly drained, peat-rich soils (i.e., anoxic, or seasonally anoxic) all derived from a largely homogeneous basaltic bedrock. These soils therefore provide an ideal natural laboratory to use $\mathrm{Fe}$ isotopes to investigate the controls on $\mathrm{Fe}$ export from soils under contrasting soil drainage, soil weathering degree and soil organic matter content. The working hypothesis of this study is that in poorly weathered well drained soils, a limited Fe isotope fractionation in solution relative to the parent basalt is expected; by contrast, in the more weathered soils, given the poor drainage and the high amount of soil organic carbon, $\mathrm{Fe}$ isotope fractionation in solution associated with reductive dissolution, ligand-controlled dissolution, and leaching of $\mathrm{Fe}(\mathrm{II})$ is expected, and $\mathrm{Fe}$-organic complexation would modify the Fe isotope fractionation driven by mineral dissolution.

Additional constraint on the advance of weathering in soils can also be obtained from silicon isotopes which are fractionated by weathering processes due to the preferential incorporation of light isotopes in secondary aluminosilicates (e.g., Ziegler et al., 2005; Georg et al., 2009; Opfergelt et al., 2010, 2012; Oelze et al., 2014). The formation of these secondary phases depends on Al availability, which in organic-rich soils is limited due to the formation of Al-organic complexes (Parfitt and Kimble, 1989; Mizota and van Reeuwijk, 1989; Parfitt, 2009). If the formation of secondary alumino-silicates is limited, the Si concentration in solution may reach supersaturation with respect to amorphous silica, for example upon freezing (Shoji and Masui, 1971; Ping et al., 1988). The precipitation of amorphous silica fractionates $\mathrm{Si}$ isotopes (e.g., Li et al., 1995; Geilert et al., 2014, 2015; Roerdink et al., 2015; Oelze et al., 2015), and would add to the Si isotope fractionation induced by clay formation. Consequently, a second working hypothesis is that $\mathrm{Si}$ isotope fractionation in soils, if partly caused by amorphous silica precipitation, indi- 
rectly provides a way to support the formation of metalorganic complexes in soils.

This study tests these two hypotheses on Icelandic soils comparing organic-poor and organic-rich soils derived from the same parental basalt. We report on $\mathrm{Fe}$ and $\mathrm{Si}$ isotope compositions of bulk soils, secondary phases, and soil solutions with a detailed soil characterisation and information on the distribution of $\mathrm{Fe}$ and $\mathrm{Si}$.

\section{MATERIALS AND METHODS}

\subsection{Environmental setting}

The types of soils developed in Iceland are primarily determined by the drainage conditions and aeolian volcanic ash inputs (Arnalds, 2004), which provide a source of fresh reactive material to the developing soils. Soils in West Iceland receive lower amounts of aeolian ash deposition $\left(\sim 0.1 \mathrm{~mm} \mathrm{yr}^{-1}\right.$; Sigfusson et al., 2008) relative to areas closer to the rift zones in South West Iceland $\left(\sim 2 \mathrm{~mm} \mathrm{yr}^{-1}\right.$; Arnalds, 2004). In areas with vegetation cover, soils are classified as Andosols ( 48\%; Haplic, Histic and Gleyic Andosols), desert areas are dominated by poorly developed Vitric Andosols ( $40 \%)$ and wetland areas by organic-rich Histosols $(\sim 1 \%)$, with the rest of Iceland $(\sim 11 \%)$ being mainly covered by glaciers (Arnalds, 2004, 2008). The andic properties of the soils and the cold climate (mean summer temperature of $12{ }^{\circ} \mathrm{C}$ ) are amongst the key factors that result in low rates of organic matter decomposition in Iceland (Guicharnaud, 2009). Oxidation is also impaired in poorly drained areas such that the accumulation of plant debris results in the progressive buildup of peat (Histic Andosol and Histosol).
The hydrology in Icelandic soils is affected by seasonal variability in runoff, which ranges from below $100 \mathrm{~mm} / \mathrm{sea}-$ son in the summer (June-July-August) to $200-400 \mathrm{~mm} / \mathrm{sea}$ son in the winter (December-January-February) (Icelandic Meteorological Office; Crochet et al., 2007). The climate in the areas of the lowland soils (below $200 \mathrm{~m}$ altitude) is temperate, with a mean annual precipitation (MAP) of $1017 \mathrm{~mm} \mathrm{yr}^{-1}$ and a mean annual temperature (MAT) of $4.6{ }^{\circ} \mathrm{C}$. Due to the maritime winter climate of Iceland, the soils are exposed to more freeze-thaw cycles than many other subarctic regions (Orradottir et al., 2008; Arnalds, 2008). This leads to seasonal wet-dry cycles that influence water mobility in soils. Recently (post 1945), Icelandic inland wetland areas have been subject to a wide-scale draining subsidy driven by agriculture, mainly for haymaking (Arnalds et al., 2016). As a result of the installed ditch network or drainage trenches, inland wetlands are now strongly affected by drainage, especially in lowland areas, where up to $70 \%$ of the wetland areas are affected. Most of the poorly drained soils (Histic Andosol and Histosol) located in the lowland areas are, therefore, affected by drainage ditches. However, Histosols are still characterised by wetter conditions (more anoxic) than Histic Andosols (Arnalds, 2008).

\subsection{Soil sampling and characterisation}

Five typical Icelandic soil types (Histic Andosol, HA; Histosol, H; Haplic Andosol, BA; Gleyic Andosol, GA; Vitric Andosol, V) under grassland were sampled in September 2009 (location in Fig. 1), including the parent basalt from the BA site, and the grass-type vegetation (hummocky grassland, bulk shoot part) was sampled in

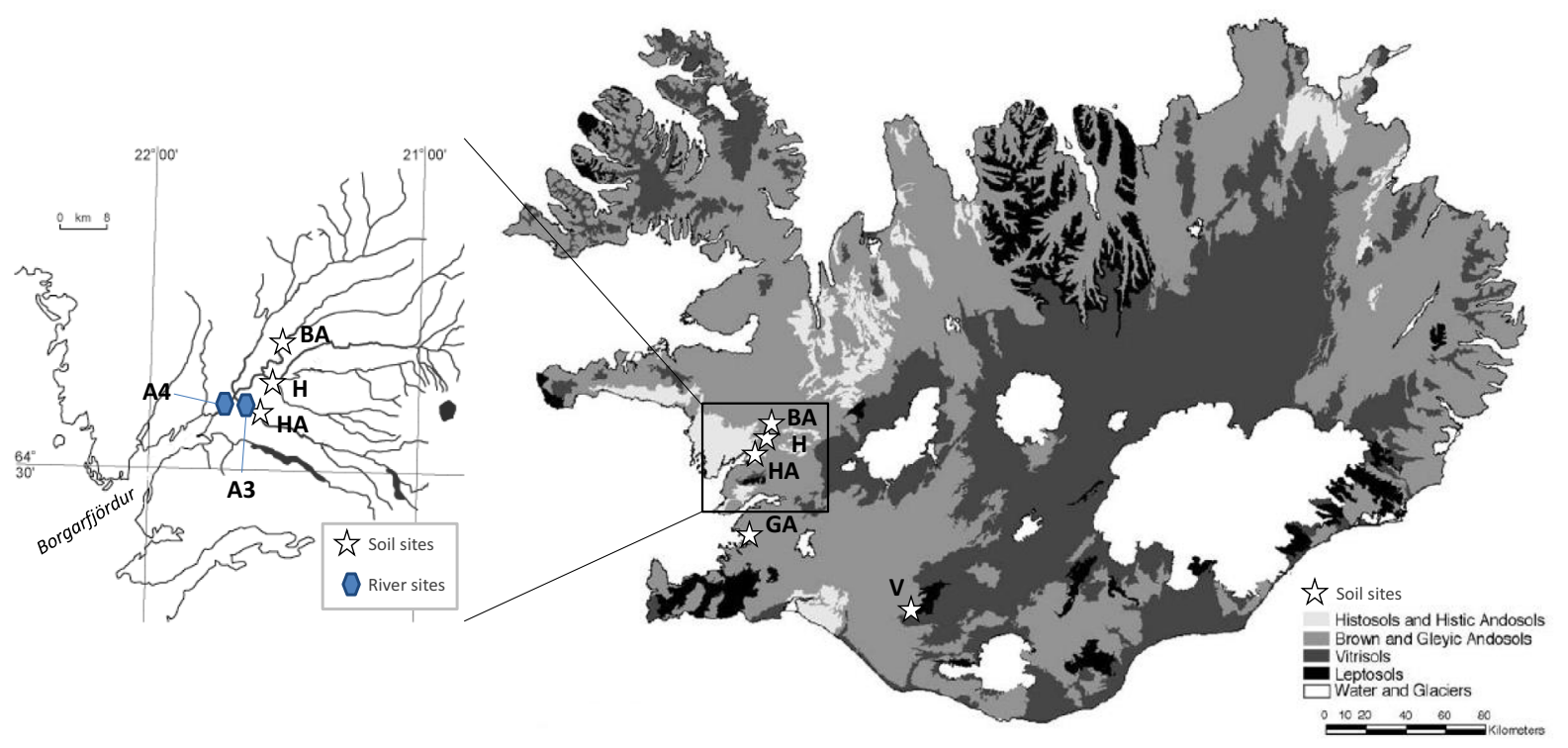

Fig. 1. Location map of the soil sites (HA, H, BA, GA, V) and the river sites (A3, A4, and HA) in Iceland studied here. Histic Andosol, HA; Histosol, H; Haplic Andosol, BA; Gleyic Andosol, GA; Vitric Andosol, V. Soil types are classified according to the World Reference Base for Soil Resources (IUSS, 2014). The soil map is based on Arnalds (2004) and Arnalds and Gretarsson (2001). 
June 2010 from the HA site. The soil profiles were described following the World Reference Base for Soil Resources (IUSS, 2014; Table EA-1) and sampled by horizon. The profiles have been characterised previously for their $\mathrm{Mg}$, Mo and $\mathrm{Zn}$ isotopic compositions (Opfergelt et al., 2014; Siebert et al., 2015; Opfergelt et al., 2017). The five soil profiles can be divided into two groups as a function of drainage: the freely drained soils V-BA-GA and the poorly drained soils HA-H. Profiles V, BA, and GA are characterised by a neutral $\mathrm{pH}$ and a low organic carbon content ( $\mathrm{pH} 6.7 \pm 0.7 ; 5.4 \pm 2.9 \% \mathrm{C}$; Table 1 ), in contrast to profiles $\mathrm{HA}$ and $\mathrm{H}$ which are acidic and organic rich soils ( $\mathrm{pH} 4.8 \pm 0.6 ; 21 \pm 9 \%$ C; Table 1; Opfergelt et al., 2014). The parent material is basaltic (main primary minerals: augite, Ca-rich plagioclase, magnetite, and glass). In volcanic soils, short-range ordered or poorly crystalline phases (i.e., aluminosilicates and Fe-oxides) are formed first (e.g., Rai and Kittrick, 1989; Thompson et al., 2011; Delmelle et al., 2015). With increasing time for soil development, the poorly crystalline phases transform to more crystalline minerals. Among the five soil profiles, the weathering degree increases in the following order: Basalt $<\mathrm{V}<\mathrm{BA}<\mathrm{GA}<\mathrm{H}<\mathrm{HA}$ (Opfergelt et al., 2014).

Iron was selectively extracted using dithionite-citratebicarbonate (DCB) $\left(\mathrm{Fe}_{\mathrm{d}}\right.$; Mehra and Jackson, 1960), ammonium oxalate $\left(\mathrm{Fe}_{\mathrm{o}}\right.$; Blakemore et al., 1981), and Na-pyrophosphate $\left(\mathrm{Fe}_{\mathrm{p}}\right.$; Bascomb, 1968) and measured by ICP-AES. The analytical conditions for these extractions are provided in Table EA-2. The DCB-extractable $\mathrm{Fe}$ is used to provide an estimate of the content of free iron oxides in soils, i.e., poorly crystalline and crystalline Feoxides. The oxalate-extractable $\mathrm{Fe}$ is used as an indicator of poorly crystalline Fe-oxides. The pyrophosphateextractable $\mathrm{Fe}$ is used as an indicator of Fe-organic complexes. These extractions are, however, to be considered with caution. Magnetite might be partly dissolved by oxalate and contribute to $\mathrm{Fe}_{\mathrm{o}}$ (e.g., Walker, 1983). The dithionite extraction is usually considered to not dissolve magnetite, but some studies report magnetite dissolution with DCB (e.g., Kostka and Luther, 1994; Henkel et al., 2016). The pyrophosphate is a dispersing agent and $\mathrm{Fe}_{\mathrm{p}}$ may include the contribution of $\mathrm{Fe}$-oxide nanoparticulates in addition to the organically-bound Fe (Jeanroy and Guillet, 1981), even if this contribution decreased by the centrifugation and filtration of the extract (Table EA-1). These selective extractions are, therefore, not fully quantitative, but can, nevertheless, be used as indicators of the evolution of the mineral phases as a function of the soil development. The $\mathrm{Fe}_{\mathrm{o}} / \mathrm{Fe}_{\mathrm{d}}$ ratio is used as a reflection of the relative proportion of short-range ordered $\mathrm{Fe}$ oxyhydroxides (ferrihydrite) in the global pool of $\mathrm{Fe}$-oxides. Within the total iron content $\left(\mathrm{Fe}_{\mathrm{t}}\right)$ in soils, the proportion of $\mathrm{Fe}$ contained in free $\mathrm{Fe}$-oxides $\left(\mathrm{Fe}_{\mathrm{d}}\right)$ is used as a weathering index (the $\mathrm{Fe}_{\mathrm{d}} / \mathrm{Fe}_{\mathrm{t}}$ ratio). The organic carbon released after dispersion by the pyrophosphate $\left(\mathrm{C}_{\mathrm{p}}\right)$ was quantified by combustion (Shimadzu TOC analyzer, detection limit $<2 \mathrm{mg} \mathrm{L}^{-1}$ ) and is considered to provide an indication of the amount of $\mathrm{C}$ that was included in metalorganic complexes (e.g. Cornu and Clozel, 2000; Cornu et al., 2008).
The oxalate-extractable $\mathrm{Si}\left(\mathrm{Si}_{\mathrm{o}}\right)$ was determined by ICPAES to estimate the quantity of $\mathrm{Si}$ associated with poorly crystalline aluminosilicates (allophane) as an indicator of the evolution of the mineral phases in soils with weathering. The $\mathrm{Si}_{\mathrm{o}}$ also includes the contribution from $\mathrm{Si}$ associated with poorly crystalline $\mathrm{Fe}$ oxyhydroxides (ferrihydrite). The $\mathrm{Si}_{\mathrm{o}}$ estimated this way is, however, to be considered with caution because volcanic glass might also be partly dissolved using this protocol, particularly at $\mathrm{pH}$ values below 6 (Oelkers and Gislason, 2001; Arnalds and Gíslason, 2002; Wolff-Boenisch et al., 2004). The DCB-extractable Si $\left(\mathrm{Si}_{\mathrm{d}}\right)$ measured by ICP-AES can be used as an indicator of Sibound to $\mathrm{Fe}$ oxyhydroxides, but is also to be considered with caution given that partial dissolution of poorlycrystalline silicate phases, such as allophane, by DCB may occur (e.g., Parfitt and Childs, 1988; Borggaard, 1988; Ryan and Gschwend, 1991). Bulk soils (<2 mm) were analysed by X-ray diffraction (XRD, Bruker D8, Cu K $\alpha$ ), after oxalate extraction to remove poorly crystalline allophane and ferrihydrite and $\mathrm{H}_{2} \mathrm{O}_{2}$ treatment to remove organic matter, to evaluate the presence of goethite and amorphous silica.

\subsection{Soil solution and river water: sampling and characterisation}

Soil solutions, i.e., pore waters from the soil profiles (except V), were sampled in June 2010, using macro rhizon soil water samplers (length $9 \mathrm{~cm}$, diameter $4.5 \mathrm{~mm}$, porosity $0.2 \mu \mathrm{m}$; Eijkelkamp ${ }^{\circledR}$ ). The soil horizons were fully saturated at the time of sampling in H-HA, but not in BAGA. The rhizon samplers were installed in soils for two weeks and collected every $24 \mathrm{~h}$ to provide a bulk soil solution (total volume of between 100 and $1500 \mathrm{ml}$ ), which was then acidified in $0.5 \% \mathrm{HNO}_{3}$ to prevent oxidative precipitation. The Fe concentrations were measured by ICP-MS, and $\mathrm{Si}$ concentrations by spectrophotometry (Opfergelt et al., 2014).

Three river water samples were collected in West Iceland in September 2009 (Fig. 1). One river sample (HA river) was collected next to the HA soil profile and the two other rivers (A3 and A4) corresponding to localities A3 and A4 previously sampled to study the influence of weathering processes on $\mathrm{U}$ and $\mathrm{Li}$ isotopes (Pogge von Strandmann et al., 2006), Mg isotopes (Pogge von Strandmann et al., 2008), and Mo isotopes (Pearce et al., 2010) were sampled again. Water was collected in pre-cleaned polypropylene bottles from the centre of the flow, and filtered within $24 \mathrm{~h}$ through $0.2 \mu \mathrm{m}$ cellulose acetate filters. The temperature, $\mathrm{pH}$, and electrical conductivity were measured in the field. For river localities A3 and A4, the $0.2 \mu \mathrm{m}$ filtered water was then ultrafiltered, using a Sartorius cross-flow filter unit containing Sartocon polyethersulphone (PESU) slice cassettes, in order to separate the colloidal fraction $(>10 \mathrm{kD})$ from the "truly" dissolved $(<10 \mathrm{kD})$ fraction. The Fe concentration in the dissolved $(<0.2 \mu \mathrm{m})$ and colloidal fraction $(10 \mathrm{kD}-0.2 \mu \mathrm{m})$ was determined by ICP$\mathrm{MS}$ in $2 \% \mathrm{HNO}_{3}$ (Open University, UK). The accuracy on the Fe concentration $( \pm 7 \% ;<0.01 \mu \mathrm{M}$ detection limit) was assessed using the water reference material SLRS-4 
Table 1

Soil parameters $\left(\mathrm{pH}\right.$, carbon and clay content), bulk soil $\mathrm{Fe}$ and $\mathrm{Si}$ content $\left(\mathrm{Fe}_{\mathrm{t}}, \mathrm{Si}_{\mathrm{t}}\right), \mathrm{Fe}$ and $\mathrm{Si}$ content in selective extracts $($ dithionite-citrate-bicarbonate $=\mathrm{d}$, oxalate $=\mathrm{o}$, pyrophosphate $=\mathrm{p})$ in soils. Iron and silicon isotope compositions of the bulk soils, secondary phases ( $\mathrm{Fe}$-oxides $\mathrm{Fe}_{\mathrm{d}}$ from $\mathrm{DCB}$ extracts for Fe isotopes, and clay fractions $<2 \mu \mathrm{m}$ for $\mathrm{Si}$ isotopes), parent basalt, and grass from the site of HA profile. Soil acronyms as in Fig. 1.

\begin{tabular}{|c|c|c|c|c|c|c|c|c|c|c|c|c|c|c|c|c|c|c|c|c|c|}
\hline \multicolumn{2}{|c|}{ Soil horizon } & \multirow{2}{*}{$\begin{array}{l}\text { Depth } \\
\mathrm{cm}\end{array}$} & \multirow[t]{2}{*}{$\mathrm{pH}_{\mathrm{H} 2 \mathrm{O}}{ }^{\mathrm{a}}$} & \multirow{2}{*}{$\begin{array}{l}\text { Carbon }^{\mathrm{a}} \\
\%\end{array}$} & \multirow{2}{*}{$\begin{array}{l}\text { Clay }^{\mathrm{a}} \\
\%\end{array}$} & \multirow{2}{*}{$\begin{array}{l}\mathrm{Fe}_{\mathrm{t}}{ }^{\mathrm{a}} \\
\mathrm{g} \\
\mathrm{kg}^{-1}\end{array}$} & \multirow{2}{*}{$\begin{array}{l}\mathrm{Si}_{\mathrm{t}}{ }^{\mathrm{a}} \\
\mathrm{g} \\
\mathrm{kg}^{-1}\end{array}$} & \multirow{2}{*}{$\begin{array}{l}\mathrm{Fe}_{\mathrm{d}} \\
\mathrm{g} \\
\mathrm{kg}^{-1}\end{array}$} & \multirow{2}{*}{$\begin{array}{l}\mathrm{Fe}_{\mathrm{o}} \\
\mathrm{g} \\
\mathrm{kg}^{-1}\end{array}$} & \multirow{2}{*}{$\begin{array}{l}\mathrm{Fe}_{\mathrm{p}} \\
\mathrm{g} \\
\mathrm{kg}^{-1}\end{array}$} & \multirow{2}{*}{$\begin{array}{l}\mathrm{Si}_{\mathrm{d}} \\
\mathrm{g} \\
\mathrm{kg}^{-1}\end{array}$} & \multirow{2}{*}{$\begin{array}{l}\mathrm{Si}_{\mathrm{o}} \\
\mathrm{g} \\
\mathrm{kg}^{-1}\end{array}$} & \multirow{2}{*}{$\begin{array}{l}\mathrm{C}_{\mathrm{p}} \\
\mathrm{g} \\
\mathrm{kg}^{-1}\end{array}$} & \multirow{2}{*}{$\begin{array}{l}\delta^{57} \mathrm{Fe}_{\text {bulk }} \\
\text { soil } \\
\% o\end{array}$} & \multirow{2}{*}{$\begin{array}{l}2 \mathrm{SD}^{\mathrm{b}} \\
\% o\end{array}$} & \multirow{2}{*}{$\begin{array}{l}\delta^{57} \mathrm{Fe}_{\mathrm{DCB}} \\
\% o\end{array}$} & \multirow{2}{*}{$\begin{array}{l}2 \mathrm{SD}^{\mathrm{b}} \\
\% o\end{array}$} & \multirow{2}{*}{$\begin{array}{l}\delta^{30} \mathrm{Si}_{\text {bulk }} \\
\text { soil } \\
\% o\end{array}$} & \multirow{2}{*}{$\begin{array}{l}2 \mathrm{SD} \\
\% 0\end{array}$} & \multirow{2}{*}{$\begin{array}{l}\delta^{30} \mathrm{Si}_{\text {clay }} \\
\% o\end{array}$} & \multirow{2}{*}{$\begin{array}{l}\mathrm{SD} \\
\% 0\end{array}$} \\
\hline & & & & & & & & & & & & & & & & & & & & & \\
\hline HA & A1 & $0-15$ & 5.32 & 18.52 & 56.1 & 165.7 & 83.4 & 129.2 & 41.5 & 43.5 & 3.7 & 8.2 & 56.6 & 0.38 & 0.08 & - & - & -1.05 & 0.09 & -1.73 & 0.10 \\
\hline HA & A2 & $15-26$ & 4.89 & 16.94 & 54.3 & 98.9 & 110.7 & 71.5 & 31.6 & 27.0 & 4.0 & 15.9 & 52.3 & 0.12 & 0.03 & 0.25 & 0.07 & -0.97 & 0.04 & -1.64 & 0.17 \\
\hline HA & Bw1 & $26-40$ & 4.82 & 14.49 & 55.2 & 175.1 & 98.0 & 139.2 & 70.0 & 33.1 & 5.5 & 13.9 & 45.0 & -0.33 & 0.07 & -0.51 & 0.07 & -1.32 & 0.05 & -1.84 & 0.15 \\
\hline HA & Bw2 & $40-57$ & 5.15 & 16.86 & 45.5 & 164.4 & 97.2 & 129.8 & 41.6 & 32.6 & 4.7 & 11.5 & 47.1 & -0.36 & 0.14 & -0.43 & 0.07 & -1.00 & 0.07 & -2.04 & 0.14 \\
\hline HA & $\mathrm{O} 1$ & $57-67$ & 4.44 & 28.71 & 53.8 & 55.7 & 55.6 & 50.9 & 25.6 & 18.7 & 4.5 & 11.0 & 74.0 & -0.16 & 0.15 & -0.19 & 0.07 & -0.77 & 0.12 & -1.11 & 0.14 \\
\hline HA & redox & $67-83$ & 4.27 & 12.79 & - & 57.6 & 185.4 & 14.0 & 8.3 & 3.7 & 2.2 & 11.5 & 30.2 & -0.05 & 0.05 & -0.71 & 0.07 & -0.42 & 0.14 & - & - \\
\hline HA & $\mathrm{O} 2$ & $83+$ & 3.93 & 42.73 & 55.3 & 42.9 & 32.0 & 40.9 & 19.1 & 16.0 & 1.9 & 2.4 & 82.5 & -0.60 & 0.07 & -0.79 & 0.07 & -0.85 & 0.04 & - & - \\
\hline $\mathrm{H}$ & $\mathrm{O} 1$ & $0-13$ & 6.18 & 21.00 & 52.3 & 120.3 & 100.4 & 99.5 & 39.8 & 11.5 & 3.7 & 4.1 & 29.6 & 0.67 & 0.07 & -0.11 & 0.04 & -0.82 & 0.09 & - & - \\
\hline $\mathrm{H}$ & $\mathrm{O} 2$ & $13-26$ & 5.10 & 22.94 & 8.4 & 83.8 & 94.9 & 57.9 & 22.6 & 18.2 & 2.4 & 3.0 & 30.3 & 0.56 & 0.07 & 0.71 & 0.02 & -1.08 & 0.05 & - & - \\
\hline $\mathrm{H}$ & O3 & $26-40$ & 4.57 & 18.62 & 38.2 & 141.7 & 91.5 & 111.4 & 34.6 & 53.1 & 4.5 & 11.1 & 49.5 & -0.02 & 0.02 & -0.05 & 0.07 & -0.73 & 0.15 & -1.42 & 0.15 \\
\hline $\mathrm{H}$ & O4 & $52-63$ & 4.66 & 10.32 & 44.4 & 101.6 & 157.6 & 79.1 & 19.6 & 35.5 & 3.4 & 7.6 & 30.6 & 0.12 & 0.07 & 0.16 & 0.05 & -0.47 & 0.08 & -0.97 & 0.15 \\
\hline $\mathrm{H}$ & O5 & $63-72$ & 4.35 & 29.27 & 70.9 & 140.7 & 40.9 & - & 27.8 & 69.1 & 4.4 & 3.8 & 59.7 & 0.30 & 0.06 & - & - & -0.68 & 0.06 & - & - \\
\hline $\mathrm{H}$ & O6 & $72+$ & 4.56 & 30.39 & 42.7 & 86.6 & 48.8 & - & 23.0 & 41.8 & 3.5 & 5.9 & 57.8 & 0.44 & 0.01 & - & - & -0.69 & 0.09 & - & - \\
\hline BA & $\mathrm{A} 1$ & $0-21$ & 6.35 & 7.29 & 33.2 & 111.9 & 158.1 & 53.4 & 45.9 & 6.8 & 2.6 & 17.9 & 22.4 & 0.08 & 0.08 & 0.08 & 0.07 & -0.53 & 0.03 & -1.07 & 0.18 \\
\hline BA & A2 & $21-40$ & 6.40 & 7.92 & 29.7 & 117.2 & 151.8 & 62.9 & 50.5 & 8.3 & 2.9 & 18.3 & 21.3 & 0.12 & 0.10 & 0.00 & 0.07 & -0.72 & 0.07 & - & - \\
\hline BA & Bw1 & $40-52$ & 6.50 & 6.47 & 37.2 & 122.7 & 150.2 & 58.3 & 43.1 & 6.3 & 3.2 & 15.4 & 16.6 & 0.14 & 0.04 & - & - & -0.67 & 0.08 & - & - \\
\hline BA & Bw2 & $52-96$ & 6.53 & 7.25 & 41.0 & 126.1 & 151.8 & 74.9 & 57.3 & 7.1 & 4.2 & 21.7 & 19.1 & 0.17 & 0.10 & 0.19 & 0.07 & -0.61 & 0.06 & -1.22 & 0.16 \\
\hline BA & $\begin{array}{l}\mathrm{Bw} 3 / \\
\mathrm{C}\end{array}$ & $96+$ & 6.24 & 5.71 & - & 127.9 & 153.4 & 59.4 & 49.7 & 6.9 & 3.3 & 21.0 & 20.7 & 0.12 & 0.06 & -0.01 & 0.07 & -0.57 & 0.10 & - & - \\
\hline GA & A1 & $0-12$ & 6.22 & 9.51 & 37.1 & 104.5 & 135.4 & 52.8 & 43.4 & 6.8 & 3.7 & 16.3 & 25.4 & 0.10 & 0.04 & 0.05 & 0.07 & -0.63 & 0.06 & -1.11 & 0.14 \\
\hline GA & A2 & $12-29$ & 6.30 & 6.20 & 41.2 & 119.2 & 149.9 & 64.4 & 50.0 & 5.1 & 4.4 & 20.4 & 16.7 & 0.10 & 0.07 & - & - & -0.61 & 0.05 & - & - \\
\hline GA & Bw1 & $29-43$ & 6.33 & 6.86 & 38.9 & 116.7 & 145.7 & 59.6 & 37.7 & 3.8 & 3.1 & 24.4 & 15.8 & 0.14 & 0.05 & -0.03 & 0.07 & -0.69 & 0.09 & -0.85 & 0.13 \\
\hline GA & Bw2 & $43-56$ & 6.34 & 6.76 & 36.3 & 105.5 & 155.5 & 49.6 & 27.3 & 2.4 & 3.0 & 25.7 & 14.9 & - & - & -1.07 & 0.04 & -0.58 & 0.06 & - & - \\
\hline GA & C & $56-64$ & 6.57 & 2.70 & - & 119.2 & 189.0 & 30.6 & 23.4 & 1.6 & 2.6 & 12.3 & 5.2 & -0.09 & 0.05 & - & - & -0.55 & 0.08 & - & - \\
\hline GA & 2Bw1 & $64+$ & 6.44 & 3.26 & 22.9 & 59.2 & 176.6 & 11.4 & 10.7 & 0.6 & 3.6 & 35.2 & 7.5 & 0.01 & 0.05 & -0.23 & 0.02 & -0.59 & 0.02 & -0.63 & 0.09 \\
\hline V & A & $0-9$ & 7.77 & 0.32 & 4.6 & 116.2 & 203.2 & 18.3 & 22.7 & 0.6 & 2.9 & 14.8 & 2.1 & - & - & - & - & -0.40 & 0.06 & - & - \\
\hline V & $\mathrm{B} / \mathrm{C}$ & 9-33 & 8.20 & 0.26 & 4.6 & 122.2 & 196.8 & 32.2 & 41.9 & 0.3 & 4.0 & 23.7 & 0.9 & - & - & - & - & -0.47 & 0.08 & - & - \\
\hline V & C & $33+$ & 7.70 & - & - & - & - & - & - & - & - & - & - & - & - & - & - & -0.38 & 0.09 & - & - \\
\hline $\begin{array}{l}\text { Pare } \\
\text { basa }\end{array}$ & & & - & - & - & 103.8 & 228.4 & - & - & - & - & - & - & - & - & - & - & -0.29 & 0.06 & - & - \\
\hline $\begin{array}{l}\text { Iceli } \\
\text { gras }\end{array}$ & & & - & - & - & - & - & - & - & - & - & - & - & -0.09 & 0.03 & - & - & - & - & - & - \\
\hline
\end{tabular}

${ }^{a}$ Data from Opfergelt et al. (2014).

${ }^{\mathrm{b}}$ In italic: for analyses where there was only enough $\mathrm{Fe}$ for 1 replicate, the $2 \mathrm{SD}$ of the in-house $\mathrm{FeCl}$ salt standard measured during the course of analysis is used. 
(measured $\mathrm{Fe}$ concentration value of $110 \pm 3 \mu \mathrm{g} \mathrm{L}^{-1}$ relative to certified value of $103 \pm 5 \mu \mathrm{g} \mathrm{L}^{-1}$; Yeghicheyan et al., 2001).

\subsection{Iron and silicon stable isotope measurements}

The $\mathrm{Fe}$ isotope compositions $\left(\delta^{57 / 54} \mathrm{Fe}\right.$, relative to the IRMM014 Fe standard) of the basalt (USGS international rock standard BIR-1 which is an Iceland basalt), bulk soil samples (except for soil profile V), selective extractions by dithionite-citrate-bicarbonate $\left(\mathrm{Fe}_{\mathrm{d}}\right.$, excluding $\mathrm{Fe}$ bound in silicates, except V; Guelke et al., 2010), soil solutions (except $\mathrm{V})$, and the vegetation sample were analysed by MC-ICPMS (Thermo Neptune) at Durham University using standard $\mathrm{Fe}$ purification and mass spectrometry procedures (Williams et al., 2012). Dissolution, Fe purification and isotope analyses were undertaken using established procedures (Williams and Bizimis, 2014). Briefly, bulk soil samples and the vegetation sample were first digested in aqua regia (3:1 $\mathrm{HCl}: \mathrm{HNO}_{3}$ ) and following a reflux and evaporation cycle, were subsequently treated with concentrated $\mathrm{HF}: \mathrm{HNO}_{3}$ $(10: 1)$ in order to dissolve any detrital material. Soil solutions and extractions were evaporated down. All samples were then oxidised with several reflux (at $150^{\circ} \mathrm{C}$ ) and evaporation (at $210^{\circ} \mathrm{C}$ ) cycles of $\mathrm{HNO}_{3}$ and $\mathrm{H}_{2} \mathrm{O}_{2}$ (repeatedly e. a. to decompose the sulphide matrix from the dithionite reagent; e.g., Henkel et al., 2016), an important step given that $\mathrm{Fe}$ isotope analysis of DCB extracts are challenging, after which they were converted to $6 \mathrm{M} \mathrm{HCl}$ form for anion column chemistry (AG1-X4, 200-400 mesh, chloride form). Iron yields were quantitative and total procedural blanks were $<0.5 \mathrm{ng}$, which is negligible compared to the total amount of $\mathrm{Fe}$ processed per soil sample or extraction $(\sim 20 \mu \mathrm{g})$. The analysed sample and standard solutions comprised $2 \mathrm{ppm} \mathrm{Fe}$ in $0.1 \mathrm{M} \mathrm{HNO}_{3}$. Sample and standard (IRMM-014) intensities $\left({ }^{56} \mathrm{Fe}\right.$ and ${ }^{54} \mathrm{Fe}$ ) were matched to within $10 \%$. The standard ${ }^{56} \mathrm{Fe}$ beam intensity was in the range 2.5 to $3.5 \times 10^{-10} \mathrm{~A}$. Measurements included collection of ${ }^{57} \mathrm{Fe},{ }^{56} \mathrm{Fe}$ and ${ }^{54} \mathrm{Fe}$ and ${ }^{53} \mathrm{Cr}$ to allow for correction of any interference of ${ }^{54} \mathrm{Cr}$ on ${ }^{54} \mathrm{Fe}$. We typically measured with a pseudo-high (peak-edge) resolution $(\mathrm{M} / \Delta \mathrm{M})$ of $\sim 8500-9000$. Errors are reported as the 2 standard deviations of replicate analyses. Mass dependence, long-term reproducibility and accuracy were evaluated by analysis of an in-house $\mathrm{FeCl}$ salt standard $\left(\delta^{57} \mathrm{Fe}=-1.05 \pm 0.07 \%\right.$, 2SD, $n=67$ ) previously analysed in other studies (Williams et al., 2014). The international rock standards BIR-1 (Icelandic basalt) and Nod-P1 (Pacific ferromanganese nodule) were analysed over the course of this study. The mean Fe isotope compositions of these standards are: $\delta^{57} \mathrm{Fe}=0.07$ $\pm 0.04 \%$ ( $2 \mathrm{SD}, n=4)$ for BIR-1, and $-0.84 \pm 0.02 \%$ for Nod-P1 (2SD, $n=7)$. These data are in excellent agreement with those reported previously (Weyer et al., 2005; Millet et al., 2012; Williams and Bizimis, 2014).

The $\mathrm{Si}$ isotope compositions $\left(\delta^{30} \mathrm{Si}\right.$, relative to the NBS$28 \mathrm{Si}$ standard) of the parent basalt (from the BA site; Opfergelt et al., 2014), bulk soil samples (all soils), clay fractions $<2 \mu \mathrm{m}$ (except $\mathrm{V}$, recovered after sonication, dispersion with $\mathrm{Na}^{+}$-saturated resin of the $<2 \mathrm{~mm}$ fraction, separation from the larger grain size by gravitational settling following the Stokes law, and flocculation of the clay particles; Rouiller et al., 1972), and soil solutions were analysed by MC-ICP-MS at the University of Oxford, UK, using standard Si purification and mass spectrometry procedures (Opfergelt et al., 2012). Briefly, solid samples were ashed at $4500^{\circ} \mathrm{C}$ and dissolved by $\mathrm{NaOH}$ fusion at $720^{\circ} \mathrm{C}$ in a silver crucible. All samples were purified for $\mathrm{Si}$ isotope measurements using cation exchange resin (BioRad AG50 W-X12) (Georg et al., 2006). Silicon isotope compositions were determined on a Nu Plasma HR-MC-ICP-MS in dry plasma mode in pseudo-high ("medium") resolution. Each sample was analysed 9 times, where each single $\delta$ value (n) represents one sample run and two bracketed standard runs. The mass dependence, accuracy and longterm reproducibility on $\delta^{30} \mathrm{Si}$ were assessed over a period of 12 months using the reference materials Diatomite $(+1.25 \pm 0.09 \%$ o, 2SD, $n=132)$, Quartz Merck $(-0.05$ $\pm 0.06 \%, 2 \mathrm{SD}, n=45)$ and the USGS rock standard BHVO-2 $(-0.26 \pm 0.09 \%, 2 \mathrm{SD}, n=124)$. These values are in excellent agreement with those reported previously (Reynolds et al., 2007; Abraham et al., 2008; Savage et al., 2010; Zambardi and Poitrasson, 2011).

\section{RESULTS}

All data are presented in Tables 1-3, in Figs. 1-6 and in Figs. EA-1 to EA-5 (for some parameters, characterisation performed on a subset of samples).

\subsection{Distribution of secondary phases in soils with weathering}

Poorly crystalline aluminosilicates such as allophane are present in a higher amount in V-BA-GA than in HA-H soils, and this is supported by a higher $\mathrm{Si}_{\mathrm{o}}$ content in $\mathrm{V}$ BA-GA $\left(20.5 \pm 6.0 \mathrm{~g} \mathrm{~kg}^{-1}\right)$ relative to HA $(10.6$ $\left.\pm 4.3 \mathrm{~g} \mathrm{~kg}^{-1}\right)$ and $\mathrm{H}\left(5.9 \pm 3.0 \mathrm{~g} \mathrm{~kg}^{-1}\right.$; Table 1). The crystalline clay minerals that have been identified are kaolinite and smectite (Opfergelt et al., 2014). The pool of free iron oxides $\left(\mathrm{Fe}_{\mathrm{d}} / \mathrm{Fe}_{\mathrm{t}}\right)$ increases with an increasing degree of weathering (Fig. 2), and the proportion of short-range ordered $\mathrm{Fe}$-oxides in the global pool of Fe-oxides $\left(\mathrm{Fe}_{\mathrm{o}} /\right.$ $\mathrm{Fe}_{\mathrm{d}}$ ratio) decreases with an increasing degree of weathering (Fig. EA-1a), suggesting that with increasing time for soil development poorly crystalline Fe-oxyhydroxides, such as ferrihydrite, transform to more crystalline phases such as goethite (shown by XRD; Fig. EA-2). The proportion of $\mathrm{Si}_{\mathrm{d}}$ is lower in V-BA-GA $\left(\mathrm{Si}_{\mathrm{d}} / \mathrm{Si}_{\mathrm{t}}=2.1 \pm 0.5 \%\right)$ than in $\mathrm{HA}$ and $\mathrm{H}(\mathrm{HA}=4.8 \pm 2.2 \% ; \mathrm{H}=3.3 \pm 1.3 \%$; Table 1$)$.

In addition to secondary aluminosilicates and $\mathrm{Fe}$-oxides, $\mathrm{Fe}$ released from the weathering of primary minerals may form metal-organic complexes. The amount of $\mathrm{Fe}_{\mathrm{p}}$ is higher in HA-H soils $\left(30.4 \pm 17.6 \mathrm{~g} \mathrm{~kg}^{-1}\right)$ than the V-BA-GA soils $\left(4.1 \pm 3.0 \mathrm{~g} \mathrm{~kg}^{-1}\right.$; Table 1), while the amounts of $\mathrm{C}_{\mathrm{p}}$ are lower in $\mathrm{V}, \mathrm{BA}$ and $\mathrm{GA}$ soils $\left(14.5 \pm 8.0 \mathrm{~g} \mathrm{~kg}^{-1}\right)$ than in $\mathrm{HA}$ and $\mathrm{H}$ soils $\left(49.6 \pm 16.9 \mathrm{~g} \mathrm{~kg}^{-1}\right.$; Table 1$)$. More specifically, the proportion of $\mathrm{Fe}_{\mathrm{p}}$ in the total soil $\mathrm{Fe}\left(\mathrm{Fe}_{\mathrm{p}} / \mathrm{Fe}_{\mathrm{t}}\right)$ is higher in $\mathrm{H}$ than in $\mathrm{HA}$, and $\mathrm{Fe}_{\mathrm{p}}$ correlates with the amount of $\mathrm{C}_{\mathrm{p}}$ in all soils (Fig. EA-1b). 
Table 2

Characterization of the soil solutions: $\mathrm{pH}$ in solution, iron and silicon concentrations in solution, and iron and silicon isotope compositions of the soil solutions. Soil acronyms as in Fig. 1.

\begin{tabular}{|c|c|c|c|c|c|c|c|c|c|}
\hline \multicolumn{2}{|c|}{ Soil horizon } & \multirow{2}{*}{$\begin{array}{l}\begin{array}{l}\text { Depth } \\
\mathrm{cm}\end{array} \\
0-15\end{array}$} & \multirow{2}{*}{$\begin{array}{l}\mathrm{pH}_{\text {solution }} \\
5.05\end{array}$} & \multirow{2}{*}{ 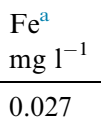 } & \multirow{2}{*}{$\frac{\mathrm{Si}^{\mathrm{a}}}{\mathrm{mg} \mathrm{1}^{-1}}$} & \multirow{2}{*}{$\begin{array}{l}\delta^{57} \mathrm{Fe} \\
\% o \\
-0.23\end{array}$} & \multirow{2}{*}{$\begin{array}{l}2 \mathrm{SD}^{\mathrm{b}} \\
\% 0 \\
0.10\end{array}$} & \multirow{2}{*}{$\begin{array}{l}\delta^{30} \mathrm{Si} \\
\% o \\
0.37\end{array}$} & \multirow{2}{*}{$\begin{array}{l}2 \mathrm{SD} \\
\% 0 \\
0.13\end{array}$} \\
\hline HA & A1 & & & & & & & & \\
\hline HA & Bw1 & $26-40$ & 4.67 & 0.023 & 9.6 & -0.08 & 0.16 & -0.19 & 0.07 \\
\hline HA & $\mathrm{O} 1$ & $57-67$ & 3.99 & 0.032 & 24.2 & -0.71 & 0.08 & 0.27 & 0.11 \\
\hline HA & redox & $67-83$ & 3.98 & 0.036 & 26.5 & -0.28 & 0.07 & 0.12 & 0.02 \\
\hline HA & $\mathrm{O} 2$ & $83+$ & 3.95 & 0.036 & 30.3 & -1.36 & 0.08 & -0.08 & 0.08 \\
\hline $\mathrm{H}$ & $\mathrm{O} 1$ & $0-13$ & 4.88 & 0.282 & 10.5 & -0.03 & 0.05 & 0.14 & 0.12 \\
\hline $\mathrm{H}$ & $\mathrm{O} 2$ & $13-26$ & 5.47 & 0.059 & 5.3 & 0.38 & 0.07 & 0.15 & 0.13 \\
\hline $\mathrm{H}$ & $\mathrm{O} 3$ & $26-40$ & 5.15 & 0.193 & 17.4 & - & - & 0.34 & 0.11 \\
\hline $\mathrm{H}$ & $\mathrm{O} 4$ & $52-63$ & - & 15.250 & 19.2 & -0.48 & 0.06 & 0.88 & 0.11 \\
\hline $\mathrm{H}$ & O5 & $63-72$ & - & - & - & - & - & - & - \\
\hline $\mathrm{H}$ & O6 & $72+$ & - & 19.980 & 18.8 & 0.14 & 0.03 & 1.22 & 0.16 \\
\hline BA & $\mathrm{A} 1$ & $0-21$ & - & 0.012 & 5.9 & -0.12 & 0.03 & 0.58 & 0.12 \\
\hline BA & $\mathrm{A} 2$ & $21-40$ & 5.84 & 0.010 & 3.5 & 0.14 & 0.09 & 0.27 & 0.10 \\
\hline $\mathrm{BA}$ & Bw1 & $40-52$ & 5.88 & 0.034 & 3.6 & -0.01 & 0.07 & -0.08 & 0.13 \\
\hline BA & $\mathrm{Bw} 2$ & $52-96$ & 5.96 & 0.008 & 4.4 & - & - & 0.15 & 0.08 \\
\hline BA & $\mathrm{Bw} 3 / \mathrm{C}$ & $96+$ & 5.46 & 0.004 & 5.0 & - & - & -0.07 & 0.06 \\
\hline GA & $\mathrm{A} 1$ & $0-12$ & - & 0.014 & 5.7 & - & - & 0.56 & 0.10 \\
\hline GA & $\mathrm{A} 2$ & $12-29$ & 5.77 & 0.045 & 7.5 & - & - & 0.05 & 0.12 \\
\hline GA & Bw1 & $29-43$ & - & 0.015 & 8.1 & - & - & 0.27 & 0.12 \\
\hline GA & Bw2 & $43-56$ & 5.6 & 0.011 & 12.0 & 0.06 & 0.07 & 0.25 & 0.09 \\
\hline GA & 2Bw1 & $64+$ & 5.46 & 0.005 & 12.4 & - & - & 0.25 & 0.07 \\
\hline
\end{tabular}

${ }^{\mathrm{a}}$ Data from Opfergelt et al. (2014).

b In italic: for analyses where there was only enough $\mathrm{Fe}$ for one replicate, the $2 \mathrm{SD}$ of the in-house $\mathrm{FeCl}$ salt standard measured during the course of analysis is used.

\subsection{Iron isotope variations in soils, soil solutions and rivers}

The poorly weathered soils (BA-GA) display relatively invariant $\mathrm{Fe}$ isotope compositions $\left(\delta^{57} \mathrm{Fe}=0.09 \pm 0.08 \%\right.$, $2 \mathrm{SD}, n=10$; Table 1; Fig. EA-3a) that are indistinguishable within error from the $\delta^{57} \mathrm{Fe}$ value of the Iceland basalt BIR$1(0.07 \pm 0.04 \%$ o, 2SD), which is considered representative of the parent material. At higher degrees of weathering and hence a higher amount of free Fe-oxides (Fig. 3a), the bulk soil $\mathrm{Fe}$ isotope compositions tend to deviate from the parent basalt composition, with a trend towards lighter values in $\mathrm{HA}\left(\delta^{57} \mathrm{Fe}=-0.14 \pm 0.33 \%, 2 \mathrm{SD}, n=7\right)$ and heavier values in $\mathrm{H}\left(\delta^{57} \mathrm{Fe}=0.34 \pm 0.26 \%\right.$, $\left.2 \mathrm{SD}, n=6\right)$. The pool of free $\mathrm{Fe}$-oxides in soils $\left(\mathrm{Fe}_{\mathrm{d}}\right)$ is characterised by $\delta^{57} \mathrm{Fe}_{\mathrm{DCB}}$ values that are generally lighter than the bulk soil (Fig. 3b) and positively correlated with the $\delta^{57} \mathrm{Fe}$ of the bulk soil $\left(\mathrm{R}^{2}=0.56\right)$. Importantly, the bulk soil and the $\mathrm{Fe}_{\mathrm{d}}$ pool of the least weathered soil $\mathrm{BA}$ are characterised by $\delta^{57} \mathrm{Fe} \quad$ values $\quad\left(\mathrm{BA}: \quad \delta^{57} \mathrm{Fe}_{\text {bulk }} \quad\right.$ soil $=0.13 \pm 0.03 \%$, $\delta^{57} \mathrm{Fe}_{\mathrm{DCB}}=0.07 \pm 0.09 \%$, 2SD) that are within error of that of the Iceland basalt BIR-1 $(0.07 \pm 0.04 \%$, 2SD), as expected. These observations provide further evidence that matrix effects do not compromise the $\mathrm{Fe}$ isotope analysis of DCB extractions (Guelke et al., 2010).

The soil solutions are characterised by low Fe concentrations in BA-GA $\left(0.02 \pm 0.01 \mathrm{mg} \mathrm{L}^{-1}, n=10\right)$ and HA $\left(0.03 \pm 0.01 \mathrm{mg} \mathrm{L}^{-1}, n=5\right)$ relative to $\mathrm{H}$ (from 0.06 to $25.07 \mathrm{mg} \mathrm{L}^{-1} \mathrm{Fe}$, with the highest concentrations in $\mathrm{H} \mathrm{O} 4$ (15.25 $\mathrm{mg} \mathrm{L}^{-1} \mathrm{Fe}$ ) and H O6 (19.98 $\mathrm{mg} \mathrm{L}^{-1} \mathrm{Fe}$; Table 2).
The $\mathrm{Fe}$ isotope compositions of the soil solutions are lighter than the bulk soils (Fig. 3c) but not systematically lighter than the $\mathrm{Fe}_{\mathrm{d}}$ pool (Fig. EA-3a). The $\delta^{57} \mathrm{Fe}$ of the soil solutions are positively correlated with the $\delta^{57} \mathrm{Fe}$ of the bulk soil $\left(\mathrm{R}^{2}=0.55\right.$; in soil horizons for which $\delta^{57} \mathrm{Fe}$ is available for bulk soils and soil solutions: BA, HA, H). There is no difference between the $\delta^{57} \mathrm{Fe}$ values in soil solutions relative to Icelandic basalt (BIR-1) in BA-GA $(0.02 \pm 0.11 \%$ o, $2 \mathrm{SD}$, $n=4)$, a trend towards lighter values relative to the basalt in HA soil solutions $\left(\delta^{57} \mathrm{Fe}\right.$ range from -1.36 to $-0.08 \%$ ), while the heaviest $\delta^{57} \mathrm{Fe}$ compositions in soil solutions are found in $\mathrm{H}$ soil solutions $\left(\delta^{57} \mathrm{Fe}\right.$ range from -0.48 to $+0.38 \%$; Fig. EA-3a). The lightest $\delta^{57} \mathrm{Fe}$ in soil solutions are found in those characterised by the lowest $\mathrm{pH}$ (Table 1; Fig. EA-3b). The soil solutions with the highest Fe concentrations ( $\mathrm{H} \mathrm{O} 4$ and $\mathrm{H} \mathrm{O} 6)$ are characterised by $\mathrm{Fe}$ isotope compositions of $-0.48 \%$ and $0.14 \%$, respectively (Fig. 3c). The Icelandic grass collected is characterized by a $\delta^{57} \mathrm{Fe}$ of $-0.09 \pm 0.03 \%$, 2SD (Table 1 ).

The river water samples collected in September 2009, A3 and A4, display similar temperature and $\mathrm{pH}$ values $\left(8.2 \pm 1.4{ }^{\circ} \mathrm{C}\right.$ and $\mathrm{pH} 8.2 \pm 0.3$; Table 3$)$ and slightly higher conductivity values $\left(57 \pm 6 \mu \mathrm{S} \mathrm{cm}^{-1}\right.$; Table 3$)$ relative to samples from the same rivers collected in September 2003 (average values for localities A3 and A4: $10.7 \pm 2.4{ }^{\circ} \mathrm{C}$, $\mathrm{pH} \quad 8.0 \pm 0.1$, conductivity $38 \pm 4 \mu \mathrm{S} \mathrm{cm}^{-1}$; Pogge von Strandmann et al., 2006). The Fe concentration in the filtered fraction of those rivers (below $0.2 \mu \mathrm{m}$ ) ranges between 6 and $11.7 \mu \mathrm{g} \mathrm{L}^{-1}$ (Table 3), with between 26 and $56 \%$ of $\mathrm{Fe}$ 
being colloidal $(10 \mathrm{kD}-0.2 \mu \mathrm{m}$; Table 3$)$. In river sample $\mathrm{A} 4$, the $\mathrm{Fe}$ isotope composition of the filtered fraction $(<0.2 \mu \mathrm{m})$ is lighter $\left(\delta^{57} \mathrm{Fe}=-0.46 \pm 0.07 \%\right.$, 2SD $)$ than the $\delta^{57} \mathrm{Fe}$ value of the colloidal fraction $(10 \mathrm{kD}-0.2 \mu \mathrm{m})$ $(-0.14 \pm 0.07 \%$, 2SD; Table 3$)$.

\subsection{Silicon isotope variations in soils and soil solutions}

Bulk soil $\mathrm{Si}$ isotope compositions are generally lighter than that of the parent basalt $\left(\delta^{30} \mathrm{Si}=-0.29 \pm 0.06 \%\right.$, $2 \mathrm{SD})$ in $\mathrm{V}(-0.42 \pm 0.05 \%, 2 \mathrm{SD}, n=3)$ and in BA-GA $(-0.61 \pm 0.06 \%$, 2SD, $n=11)$, and are the lightest and most variable in $\mathrm{HA}(-0.91 \pm 0.28 \%$ o $2 \mathrm{SD}, n=7)$ and $\mathrm{H}$ $(-0.74 \pm 0.20 \%, n=6,2 \mathrm{SD}$; Table 1 ; Fig. EA-4a). The $\delta^{30} \mathrm{Si}$ values of the bulk soil samples become progressively lighter with greater degree of weathering, as defined using the amount of free Fe-oxide $\left(\mathrm{R}^{2}=0.47\right.$; Fig. $\left.4 \mathrm{a}\right)$. The data indicate that above $45 \%$ clay content $(<2 \mu \mathrm{m}$; granulometric clay fraction with clay minerals and Fe-oxides as the main mineral constituents), the $\mathrm{Si}$ isotope composition of the bulk soils becomes systematically lighter (Table 1). The $\delta^{30} \mathrm{Si}$ of the clay fractions are lighter than the $\delta^{30} \mathrm{Si}$ of the bulk soil, with a trend towards lighter $\delta^{30} \mathrm{Si}$ clay with increasing weathering from BA-GA to HA (Fig. 4b).

The $\mathrm{Si}$ concentrations in soil solutions in HA $(20.03$ $\left.\pm 9.75 \mathrm{mg} \mathrm{L}^{-1}, n=5\right)$ are higher than in BA-GA $(6.80$ $\pm 3.21 \mathrm{mg} \mathrm{L}^{-1}, n=10$ ), whereas $\mathrm{H}$ soil solutions display $\mathrm{Si}$ concentrations $\left(14.25 \pm 6.13 \mathrm{mg} \mathrm{L}^{-1}, n=5\right.$; Table 2) that fall between those from BA-GA and HA but are not significantly different from each other. The Si concentrations in soil solutions increase at lower $\mathrm{pH}\left(\mathrm{R}^{2}=0.79\right.$; Table 1; Fig. EA-4b). The Si isotope compositions of soil solutions are heavier $(+0.29 \pm 0.37 \%$, $2 \mathrm{SD}, n=30$; Table 2$)$ than the bulk soils (Fig. 4c) and the Icelandic basalt (Fig. EA-4a). There is no difference in $\delta^{30} \mathrm{Si}$ between the BA-GA and HA-H soil solutions (Table 2). The heaviest $\delta^{30} \mathrm{Si}$ values in soil solutions are found in the deep horizons of the $\mathrm{H}$ soil profile $(\mathrm{H} \mathrm{O} 4+0.88 \%$ and $\mathrm{H} \mathrm{O} 6+1.22 \%$; Fig. 4c).

\section{DISCUSSION}

\subsection{Iron isotope fractionation in soils}

The $\delta^{57} \mathrm{Fe}$ value of the Icelandic basalt used as representative of the parent material (BIR-1 $=0.07 \pm 0.04 \%$, 2SD) is within the range of terrestrial igneous rocks $(-0.1$ to $+0.15 \%$; Beard et al., 2003; Fig. 5a). The range of $\delta^{57} \mathrm{Fe}$ observed in bulk Icelandic soils $(-0.60$ to $+0.67 \%$ ) is within that of existing iron isotope data for soils (recalculated where necessary from $\delta^{56} \mathrm{Fe}$ to $\delta^{57} \mathrm{Fe}$ using the massdependent scaling factor of 1.5 ; e.g., from -0.9 to +1.4\%o; Fantle and DePaolo, 2004; Emmanuel et al., 2005; Thompson et al., 2007; Wiederhold et al., 2007a; Mansfeldt et al., 2012; Fekiacova et al., 2013; Liu et al., 2014; Akerman et al., 2014; Liu et al., 2014; Schulz et al., 2016; Fig. 5a), including soils that formed in both oxic and anoxic weathering conditions. The $\delta^{57} \mathrm{Fe}$ values of the free $\mathrm{Fe}$ oxide pool $(-1.07$ to $+0.25 \%)$ are within the range of published values for pedogenic Fe-oxides $(-1.07$ 


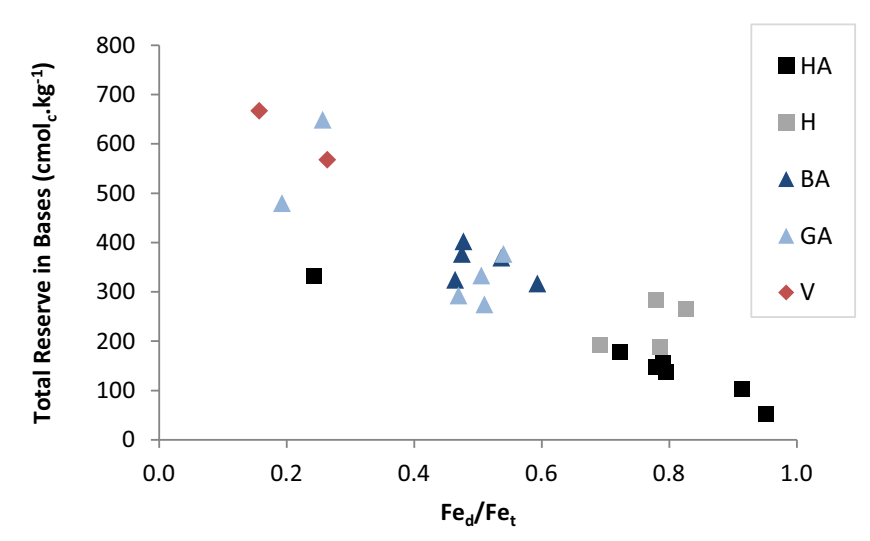

Fig. 2. The degree of weathering in soils: The HA-H soils, with low Total Reserve in Bases $(\mathrm{TRB}=[\mathrm{Na}]+[\mathrm{Mg}]+[\mathrm{Ca}]+[\mathrm{K}]$; Herbillon, 1986; data from Opfergelt et al., 2014) and a high proportion of free iron $\left(\mathrm{Fe}_{\mathrm{d}} / \mathrm{Fe}_{\mathrm{t}}\right)$ are more weathered than V-BA-GA soils with higher TRB and lower $\mathrm{Fe}_{\mathrm{d}} / \mathrm{Fe}_{\mathrm{t}}\left(\mathrm{Fe}_{\mathrm{d}}=\mathrm{Fe}\right.$ extracted by DCB or dithionite-citrate-bicarbonate; $\mathrm{Fe}_{\mathrm{t}}=\mathrm{Fe}$ total $)$. Soil acronyms as in Fig. 1.

to $+0.90 \%$; Wiederhold et al., 2007b; Poitrasson et al., 2008; Guelke et al., 2010; Kiczka et al., 2011; Yesavage et al., 2012; Liu et al., 2014; Schuth and Mansfeldt 2015; Fig. 5a).

Minimal $\delta^{57} \mathrm{Fe}$ variations in the BA-GA bulk soils $(0.09$ $\pm 0.08 \%$ o, $2 \mathrm{SD})$ relative to the parent basalt $(0.07 \pm 0.04 \%$, 2SD) likely reflect the low degree of weathering of these soils, and the lower amount of $\mathrm{Fe}$-oxyhydroxides present compared to the HA-H soils (Fig. 3a). This is supported by the "basalt-like" $\delta^{57} \mathrm{Fe}$ ratio in the volcanic ash horizon HA soil profile (HA redox, 67-83 cm depth $=-0.05$ $\pm 0.05 \%$, 2SD; Fig. 3a; Table EA-1). In this volcanic ash layer, the heavier $\delta^{57} \mathrm{Fe}$ value with respect to the rest of the profile reflects the lower weathering degree of the material, i.e., a lower proportion of Fe-oxyhydroxides (Fig. 2). Aeolian deposition of volcanic ash at the top of the soils also contributes to soil formation in Iceland (Arnalds, 2008). However, the influence of volcanic ash on soil Fe isotope compositions is likely to be limited given that the aeolian contribution in the area of BA-GA-HA-H soils in West Iceland are low ( $\sim 0.1 \mathrm{~mm} \mathrm{yr}^{-1}$; Sigfusson et al., 2008) when compared to areas closer to the rift zones in South West Iceland ( $2 \mathrm{~mm} \mathrm{yr}^{-1}$; Arnalds, 2004).

The $\delta^{57} \mathrm{Fe}$ values in HA bulk soils are heavier than the basalt at the surface and lighter than the basalt below 25 $\mathrm{cm}$ depth (Fig. EA-3a). The poorly drained conditions of this profile are likely to favour the release of isotopically light $\mathrm{Fe}(\mathrm{II})$ under anoxic conditions, followed by the quantitative precipitation of Fe-oxides during fluctuating oxic conditions (e.g., Fekiacova et al., 2013; Yesavage et al., 2016) resulting in the enrichment of light $\mathrm{Fe}$ isotopes in pedogenic oxides in these soils (Wiederhold et al., 2007a; Guelke et al., 2010; Kiczka et al., 2011). This hypothesis is supported by the lighter $\delta^{57} \mathrm{Fe}_{\mathrm{DCB}}$ composition of the $\mathrm{Fe}_{\mathrm{d}}$ pool relative to the bulk soils (Fig. 3b) indicating a preferential retention of light $\mathrm{Fe}$ isotopes in Fe-oxides. The fluctuations of oxic-anoxic conditions are generated by frequent seasonal freeze-thaw cycles (Orradottir et al., 2008), and these fluctuations occur more regularly in HA than $\mathrm{H}$ (Arnalds, 2008), and are amplified by drainage ditches in wetlands (Arnalds et al., 2016). In addition, the presence of Fe-organic complexes may contribute to the $\mathrm{Fe}$ isotope variability in the HA profile $\left(\delta^{57} \mathrm{Fe}=-0.14\right.$ $\pm 0.33 \%$, 2SD), and lead to the heavier $\delta^{57} \mathrm{Fe}$ relative to the basalt observed above $25 \mathrm{~cm}$. Iron-organic ligand complexation has been experimentally shown to favour heavy Fe isotopes (Dideriksen et al., 2008; Morgan et al., 2010), as predicted by the isotope fractionation theory for a stronger bonding environment (Schauble, 2004). The correlation between $\mathrm{Fe}_{\mathrm{p}} / \mathrm{Fe}_{\mathrm{t}}$ and $\mathrm{C}_{\mathrm{p}}$ (Fig. EA-1b) supports the presence of Fe-organic complexes in both $\mathrm{HA}$ and $\mathrm{H}$ soils. The formation of metal-organic complexes is favoured by the higher amounts of organic carbon available in the HA-H soils relative to the BA-GA soils (Table 1), and by the lower $\mathrm{pH}$ in the HA-H soils than in BA-GA soils (Table 1) enhancing the rate of glass dissolution (Oelkers and Gislason, 2001) and thereby creating a larger dissolved Fe pool.

The $\delta^{57} \mathrm{Fe}$ values in the $\mathrm{H}$ bulk soils are heavier than the basalt suggesting the loss of light Fe isotopes from this soil. The poorly drained conditions (mainly anoxic) of this profile are likely to favour the release of isotopically light $\mathrm{Fe}$ (II) by reductive dissolution. The reduction of $\mathrm{Fe}$ is known to lead to a fractionation of $\mathrm{Fe}$ isotopes, with $\mathrm{Fe}(\mathrm{II})$ being isotopically lighter than Fe(III) (Welch et al., 2003; Thompson et al., 2007; Wiederhold et al., 2007a; Wu et al., 2011), and the greater mobility of $\mathrm{Fe}(\mathrm{II})$ in aqueous solutions during weathering and soil development progressively depletes the soil in light $\mathrm{Fe}$ isotopes, and leaves the residual material enriched in heavy $\mathrm{Fe}$ (e.g., Wiederhold et al., 2007a; Fekiacova et al., 2013; Akerman et al., 2014; Schuth et al., 2015). The existence of drainage ditches in wetlands (Arnalds et al., 2016) can potentially expose the $\mathrm{H}$ soil profile to oxic conditions for short periods of time, which could explain the presence of secondary Fe-oxides in this soil and the range of $\mathrm{Fe}$ isotope variability of the bulk soils $\left(\delta^{57} \mathrm{Fe}=0.34 \pm 0.26 \%\right.$, 2SD $)$. The variable $\delta^{57} \mathrm{Fe}$ isotope composition of the $\mathrm{Fe}_{\mathrm{d}}$ pool is similar to or heavier than the bulk soil in the $\mathrm{H}$ profile (except one lighter value; Fig. 3 b) and this suggests that the quantitative precipitation of Fe-oxides has occurred following a loss of light $\mathrm{Fe}$ isotopes. In addition, the formation and quantita- 

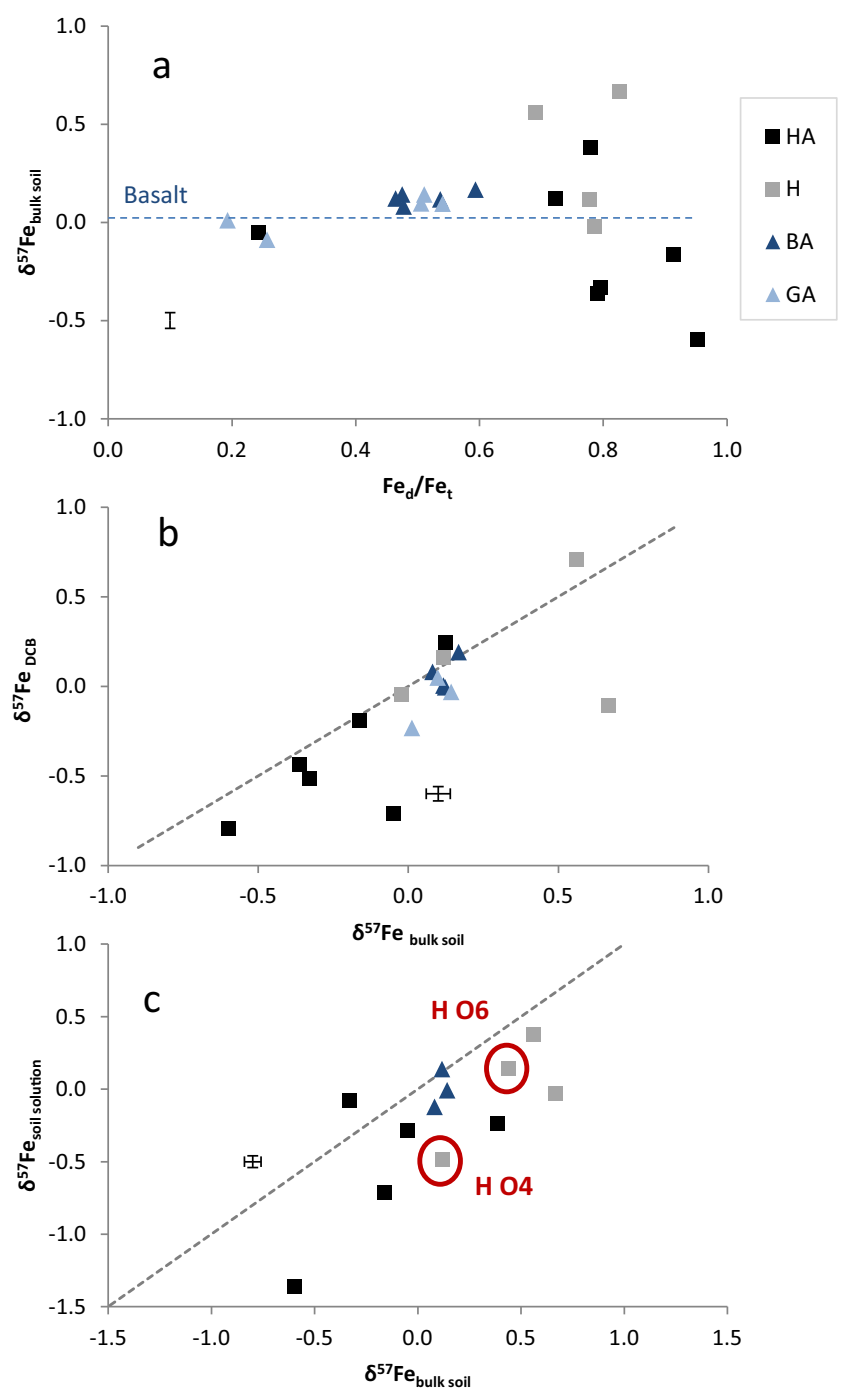

Fig. 3. (a) The relation between the Fe isotope composition in bulk soils $\left(\delta^{57} \mathrm{Fe}_{\text {bulk soil }}, 2 \mathrm{SD}\right)$ and the proportion of free iron $\left(\mathrm{Fe}_{\mathrm{d}} / \mathrm{Fe}_{\mathrm{t}}\right.$, with $\mathrm{Fe}_{\mathrm{d}}=\mathrm{Fe}$ extracted by DCB or dithionite-citrate-bicarbonate; $\mathrm{Fe}_{\mathrm{t}}=\mathrm{Fe}$ total), the $\delta^{57} \mathrm{Fe}$ of the basalt BIR-1 considered as representative of the parent material is given by the horizontal line for comparison; (b) The relation between the Fe isotope composition of the free iron pool extracted by DCB $\left(\delta^{57} \mathrm{Fe}_{\mathrm{DCB}}, 2 \mathrm{SD}\right)$ and the $\delta^{57} \mathrm{Fe}_{\text {bulk soil }}$, 2SD; a 1:1 line is provided for comparison; (c) The relation between the $\mathrm{Fe}$ isotope composition of the soil solution $\left(\delta^{57} \mathrm{Fe}_{\text {soil solution }}, 2 \mathrm{SD}\right)$ and the $\delta^{57} \mathrm{Fe}_{\text {bulk soil }}, 2 \mathrm{SD}$; a 1:1 line is provided for comparison, and the two horizons with the highest Fe soil solution concentrations, H O4 and H O6, are identified (Table 2). Soil acronyms as for Fig. 1 (no data available for V).

tive accumulation of $\mathrm{Fe}$-organic complexes may contribute to the $\mathrm{Fe}$ isotope variability in the $\mathrm{H}$ profile. This process is likely to occur to a greater extent in $\mathrm{H}$ than in $\mathrm{HA}$, given the anoxic conditions releasing $\mathrm{Fe}$ by reductive dissolution (highest $\mathrm{Fe}$ concentration in soil solution in $\mathrm{H}$; Table 1), resulting in the higher proportion of $\mathrm{Fe}_{\mathrm{p}}$ in the $\mathrm{H}$ soil than in the HA soil (higher $\mathrm{Fe}_{\mathrm{p}} / \mathrm{Fe}_{\mathrm{t}}$; Fig. EA-1b).

Iron recycling by vegetation, including plant $\mathrm{Fe}$ uptake and decomposition of organic matter, is likely to contribute to the $\mathrm{Fe}$ isotope variability in soils, especially in organicrich soils such as HA-H. The $\delta^{57} \mathrm{Fe}$ value in plant available from the HA site (Icelandic grass: $\delta^{57} \mathrm{Fe}=-0.09 \pm 0.03 \%$, 2SD; Table 1) is isotopically similar or heavier than the HA soil solution (Table 2). However, the Fe isotope fractionation in plants is still debated (e.g., Guelke-Stelling and von Blanckenburg, 2012; Caldelas and Weiss 2017) as it may depend on different parameters such as the plant $\mathrm{Fe}$ acquisition strategy (Marschner and Römheld, 1994; Guelke and von Blanckenburg, 2007) or the nutrient status of the soils (Kiczka et al., 2010b). It is therefore difficult to predict if heavier or lighter $\mathrm{Fe}$ isotopes are preferentially taken up by vegetation at the studied field sites based on the available data. The Fe concentrations of vegetation from the BA-GA-HA-H soils ranges from 0.2 to $0.4 \mathrm{~g} \mathrm{~kg}^{-1}$ (Opfergelt et al., 2014), in good agreement with reported values for $\mathrm{Fe}$ concentrations in Icelandic grass 0.1-1.4 $\mathrm{g} \mathrm{kg}^{-1}$ (e.g., Johannesson et al., 2007). Taking a biomass production of $\sim 2 \mathrm{t} \mathrm{ha}^{-1} \mathrm{yr}^{-1}$ (Opfergelt et al., 2014), the Fe uptake by vegetation ranges from 0.4 to $0.9 \mathrm{~kg} \mathrm{ha}^{-1}$ $\mathrm{yr}^{-1}$. Relative to the total soil Fe reservoir (between 134 and $338 \mathrm{~kg} \mathrm{ha}^{-1}$ in the top $40 \mathrm{~cm}$ of the soil profile, calculated for each profile from the total $\mathrm{Fe}$ concentration in soil 

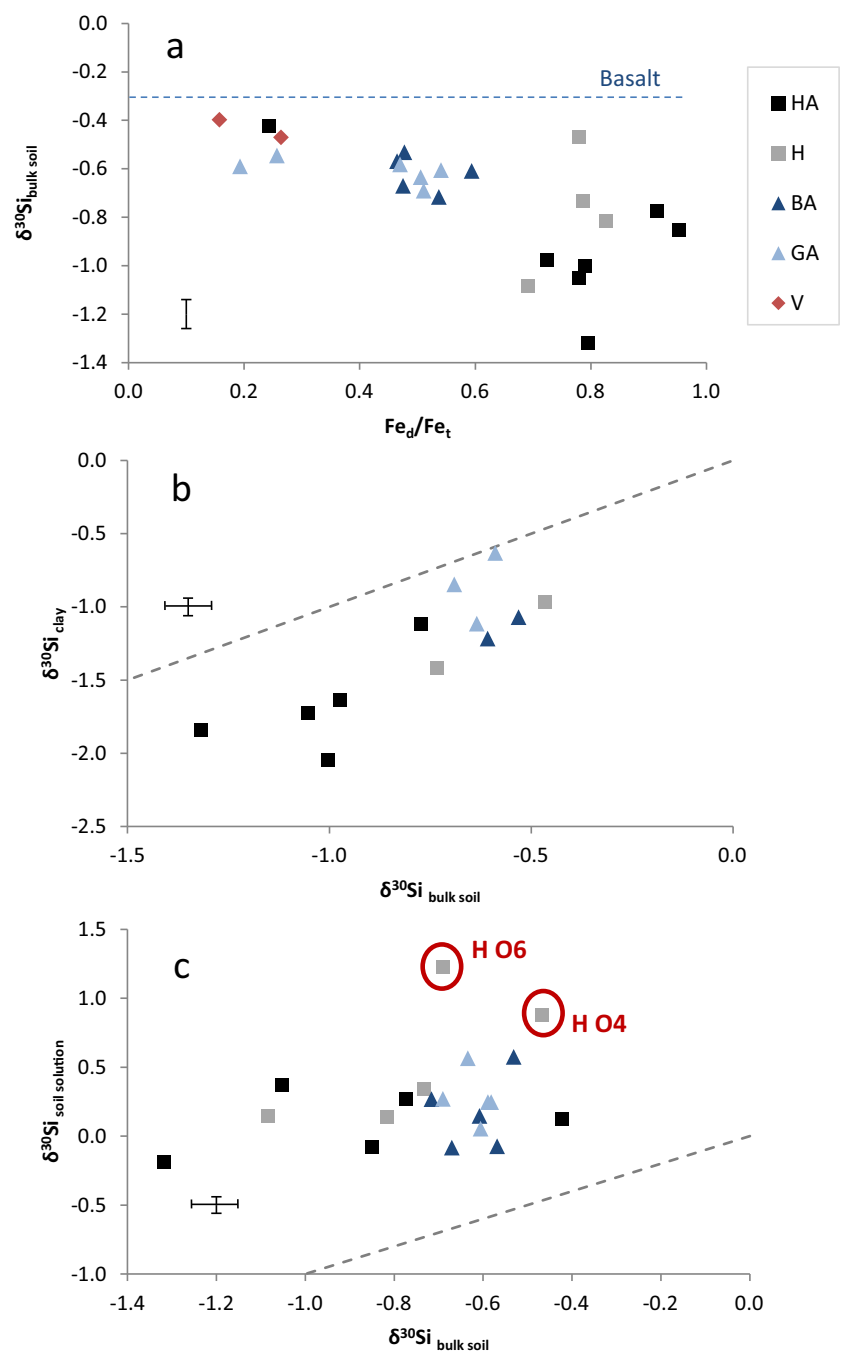

Fig. 4. (a) The $\mathrm{Si}$ isotope composition in the bulk soils $\left(\delta^{30} \mathrm{Si}_{\text {bulk soil }}, 2 \mathrm{SD}\right)$ decreases with increasing degree of soil weathering, as shown by the proportion of free iron $\left(\mathrm{Fe}_{\mathrm{d}} / \mathrm{Fe}_{\mathrm{t}}\right.$, with $\mathrm{Fe}_{\mathrm{d}}=\mathrm{Fe}$ extracted by DCB or dithionite-citrate-bicarbonate; $\mathrm{Fe}_{\mathrm{t}}=\mathrm{Fe}$ total), from V to BA-GA to $\mathrm{HA}-\mathrm{H}$. The $\delta^{30} \mathrm{Si}$ of the parent basalt is given by the horizontal line for comparison. (b) The Si isotope composition of the clay fractions $\left(\delta^{30} \mathrm{Si}_{\text {clay }}, 2 \mathrm{SD} ;<2 \mu \mathrm{m}\right)$ as a function of the $\delta^{30} \mathrm{Si}_{\text {bulk soil }}, 2 \mathrm{SD}$; a $1: 1$ line is provided for comparison. (c) The $\mathrm{Si}$ isotope composition of the soil solution $\left(\delta^{30} \mathrm{Si}_{\text {soil solution, }} 2 \mathrm{SD}\right)$ as a function of the $\delta^{30} \mathrm{Si}_{\text {bulk soil }}, 2 \mathrm{SD}$; a $1: 1$ line is provided for comparison, and the two horizons with the highest $\delta^{30} \mathrm{Si}_{\text {soil solution }}, \mathrm{H} \mathrm{O} 4$ and H O6, are identified (Table 2). Soil acronyms as for Fig. 1 (no data available for V in the clay fraction and in soil solution).

horizons above $40 \mathrm{~cm}$ in Table 1 , and the bulk density of soil horizons provided in Opfergelt et al., 2014), the annual Fe uptake in vegetation represents $0.3 \%$ to $0.6 \%$ of the soil $\mathrm{Fe}$ reservoir. Therefore, although $\mathrm{Fe}$ recycling by vegetation may contribute to the overall $\mathrm{Fe}$ isotope variability in bulk soils, this contribution is limited relative to the other processes previously discussed.

\subsection{Controls on $\mathrm{Fe}$ in soil solutions}

The $\delta^{57} \mathrm{Fe}$ values of the soil solutions, generally lighter than their corresponding bulk soils (Fig. 3c), indicate the preferential release of light $\mathrm{Fe}$ isotopes in the dissolved pool relative to the solid pool, or a preferential removal of heavy $\mathrm{Fe}$ isotopes from the soil solution. The limited Fe isotope fractionation in soil solutions relative to the bulk soil in
BA-GA $\left(\Delta^{57} \mathrm{Fe}_{\text {solution-soil }}=-0.11 \pm 0.12 \%\right.$; Fig. 6) reflects the limited $\mathrm{Fe}$ isotope fractionation in poorly weathered soils (Fig. EA-3a): the trend to release light Fe isotopes likely reflects primary mineral weathering by protonpromoted dissolution (Chapman et al., 2009; Kiczka et al., 2010a).

The $\delta^{57} \mathrm{Fe}$ values in the HA soil solutions are lighter relative to the bulk soil except for HA Bw1 where the solution is heavier $\left(\Delta^{57} \mathrm{Fe}_{\text {solution-soil }}\right.$ in $\mathrm{HA}=-0.76$ to $+0.25 \%$; Fig. 6). The dissolution of glass is favoured given the low $\mathrm{pH}$ of the HA soil (as supported by the high Si concentration in solution; Fig. EA-4b). Given that the HA soil is organic-rich, ligand-controlled mineral dissolution is likely to contribute to the release of $\mathrm{Fe}$, favouring light $\mathrm{Fe}$ isotopes. In this soil, characterised by fluctuating oxic-anoxic conditions, reductive dissolution is likely to occur and 


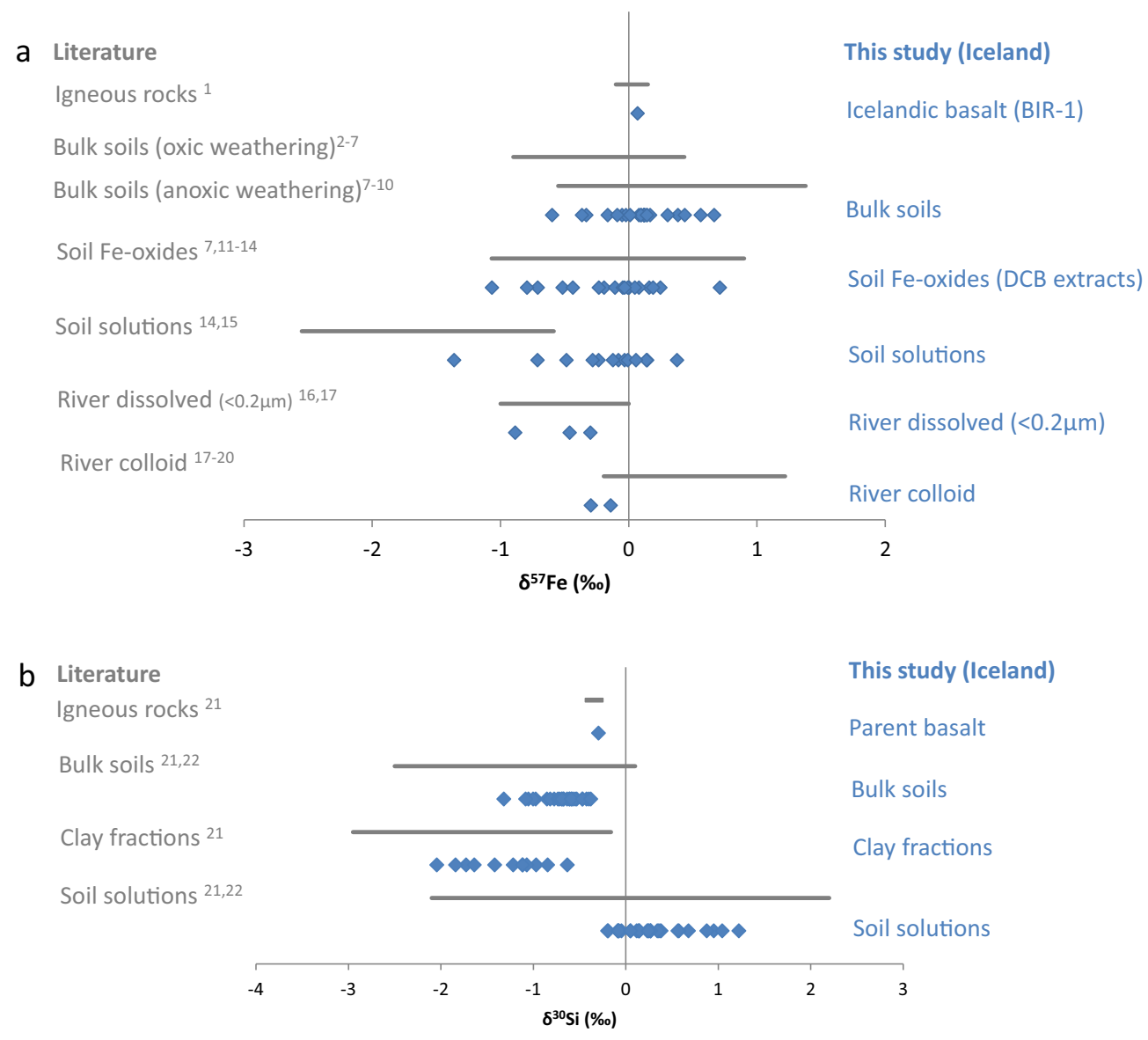

Fig. 5. (a) Comparison between the main terrestrial $\mathrm{Fe}$ isotope variations $\left(\delta^{57} \mathrm{Fe}\right)$ in igneous rocks, soils and rivers in the literature and the present study. (b) Comparison between the main terrestrial $\mathrm{Si}$ isotope variations $\left(\delta^{30} \mathrm{Si}\right)$ in igneous rocks, soils, clay fractions, clay fractions from Cameroon with and without Fe-oxides, and soil solutions in the literature and the present study. [1] Beard et al. (2003), [2] Fantle and De Paolo (2004), [3] Emmanuel et al. (2005), [4] Fekiacova et al. (2013), [5] Mansfeldt et al. (2012), [6] Liu et al. (2014), [7] Fekiacova et al. (2017), [8] Thompson et al. (2007), [9] Akerman et al. (2014), [10] Schulz et al. (2016), [11] Wiederhold et al. (2007b), [12] Kiczka et al. (2011), [13] Yesavage et al. (2012), [14] Schuth and Mansfeldt (2015), [15] Garnier et al. (2017), [16] Bergquist and Boyle (2006), [17] Mulholland et al. (2015), [18] Ilina et al. (2013), [19] Escoube et al. (2015), [20] Ingri et al. (2006), [21] review in Opfergelt and Delmelle (2012), [22] review in Frings et al. (2016). Results expressed as $\delta^{56} \mathrm{Fe}$ in the literature were converted to $\delta^{57} \mathrm{Fe}$ using the mass-dependent scaling factor of 1.5 .

release light $\mathrm{Fe}$ isotopes during periods of anoxia. Iron reduction may mobilize colloidal Fe-organic complexes and Fe-oxides from the soil (Thompson et al., 2011; Buettner et al., 2014). Mobilisation of colloidal Fe-oxides to soil solutions can provide some explanation of the lighter $\delta^{57} \mathrm{Fe}$ in soil solutions relative to bulk soils, given that the $\delta^{57} \mathrm{Fe}_{\mathrm{DCB}}$ is similar to or lighter than the $\delta^{57} \mathrm{Fe}$ of bulk soils (Fig. 3b). Mobilisation of colloidal Fe-organic complexes, e.g., from the surface horizon HA A1 and horizon A2, may contribute to the heavier $\delta^{57} \mathrm{Fe}$ values in the soil solution of the horizon HA Bw1, given that organic-Fe complexation favours heavy $\mathrm{Fe}$ isotopes (Dideriksen et al., 2008; Morgan et al., 2010).

The $\delta^{57} \mathrm{Fe}$ values in $\mathrm{H}$ soil solutions are lighter than the bulk soil $\left(\Delta^{57} \mathrm{Fe}_{\text {solution-soil }}=-0.45 \pm 0.24 \%\right.$; Fig. 6), but not as light as the HA soil solutions relative to the bulk soil $\left(\Delta^{57} \mathrm{Fe}_{\text {solution-soil }}\right.$ up to $-0.76 \%$ in HA). The poorly drained conditions (mainly anoxic) in $\mathrm{H}$ soil favour reductive dissolution and the release of isotopically light $\mathrm{Fe}(\mathrm{II})$ (Welch et al., 2003; Thompson et al., 2007; Wiederhold et al., 2007a; Wu et al., 2011), and this is supported by the highest $\mathrm{Fe}$ concentrations in solution in $\mathrm{H}$, especially at depth (below $52 \mathrm{~cm}$ depth, in $\mathrm{H} \mathrm{O} 4$ and $\mathrm{H} \mathrm{O6,} 15.25$ and 19.98 $\mathrm{mg} \mathrm{L}^{-1} \mathrm{Fe}$, respectively), relative to the other soil profiles (BA-GA: $0.02 \pm 0.01 \mathrm{mg} \mathrm{L}^{-1}, \quad n=10 ; \quad \mathrm{HA}: \quad 0.03 \pm 0.01$ $\mathrm{mg} \mathrm{L}^{-1}, n=5$; Table 2). In addition, as for the soil profile HA, ligand-controlled mineral dissolution may also contribute to the release of light $\mathrm{Fe}$ isotopes in the $\mathrm{H}$ soil solutions, and Fe reduction may mobilize colloidal $\mathrm{Fe}$ as Fe-organic complexes or Fe-oxides (Thompson et al., 2011; Buettner et al., 2014) and contribute to the $\delta^{57} \mathrm{Fe}$ variability in solutions. The soil solutions of $\mathrm{H} \mathrm{O} 4$ and $\mathrm{H} \mathrm{O} 6$ are dominated by dissolved $\mathrm{Fe}(\mathrm{II})$ released under anoxic conditions, as supported by the high Fe concentrations in these soil solutions. Interestingly, the H O6 soil solution, which is characterised by a higher Fe concentration (19.9 $\left.\mathrm{mg} \mathrm{L}^{-1} \mathrm{Fe}\right)$, is isotopically heavier $(0.14 \%$ ) than the soil solution of $\mathrm{H} \mathrm{O} 4(-0.48 \%$; Fig. 3c) which has a lower $\mathrm{Fe}$ 
V-BA-GA

Mainly oxic conditions
HA

Alternating oxic-anoxic conditions
H

Mainly anoxic conditions
Drainage

Weathering degree and organic carbon content

Soil pH

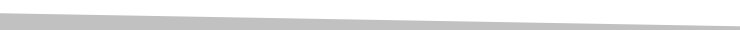

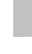

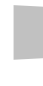

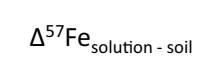

$\Delta^{30} \mathrm{Si}_{\text {solution - soil }}$

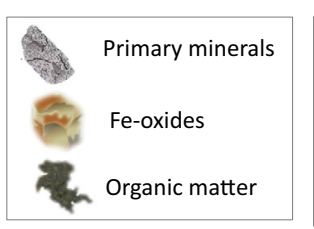

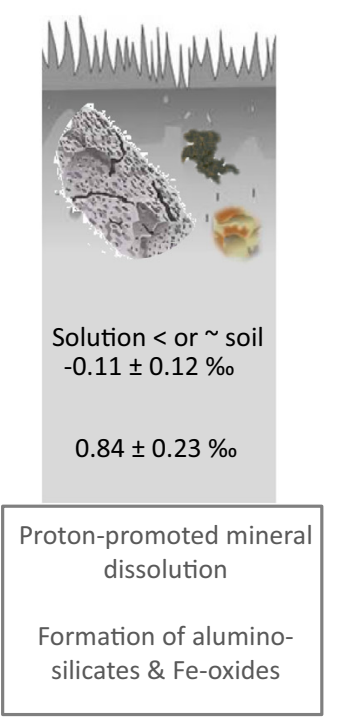

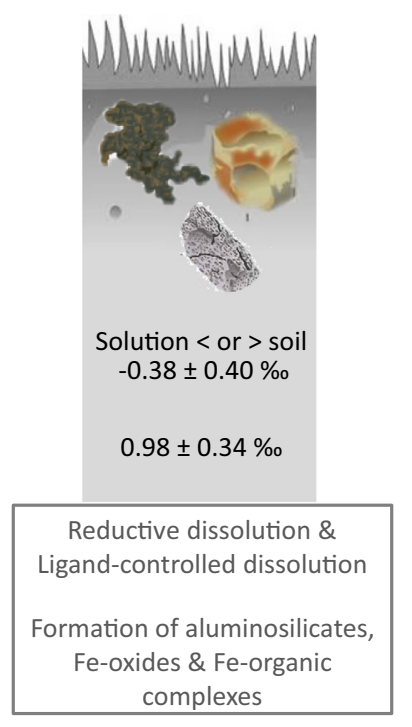

Fig. 6. Conceptual view (no scale) of the main processes controlling Fe release from soils based on the difference in Fe and $\mathrm{Si}$ isotope composition between soil solutions and bulk soils (e.g., $\Delta^{30} \mathrm{Si}_{\text {solution-soil }}=\delta^{30} \mathrm{Si}_{\text {soil solution }}-\delta^{30} \mathrm{Si}_{\text {bulk soil }}$ ). Schematic soil constituents modified from Chorover et al. (2007). Soil acronyms as for Fig. 1.

concentration (15.2 $\mathrm{mg} \mathrm{L}^{-1} \mathrm{Fe}$; Table 2). These observations suggest that the $\delta^{57} \mathrm{Fe}$ in $\mathrm{H}$ soil solutions is not only driven by light $\mathrm{Fe}(\mathrm{II})$ (Johnson et al., 2008), but modified towards heavier $\delta^{57} \mathrm{Fe}$ values by the preferential retention of heavy $\mathrm{Fe}$ isotopes in solution, relative to the more mobile and isotopically lighter Fe(II). The formation of Fe-organic complexes in solution is expected to favour the incorporation of heavy Fe isotopes (Dideriksen et al., 2008; Morgan et al., 2010). The formation of Fe-organic complexes in the $\mathrm{H}$ soil profile is consistent with the higher $\mathrm{Fe}_{\mathrm{p}} / \mathrm{Fe}_{\mathrm{t}}$ of the bulk $\mathrm{H}$ soil relative to the other soils (Fig. EA-1b). These observations point to a contribution from colloidal $\mathrm{Fe}$-organic complexes in soil solutions from the $\mathrm{H}$ soil profile, i.e., characterised by more anoxic conditions (Fig. 6). This is consistent with observations in a tropical setting in Brazil, where Fe is leached from soils as Fe-organic complexes in lowlands characterised by poorly drained (waterlogged) organic-rich environments involving $\mathrm{Fe}$ reductive dissolution in anoxia (Chauvel et al., 1987; Lucas et al., 1987; Fritsch et al., 2011).

\subsection{Silicon isotope fractionation in soils}

The $\delta^{30} \mathrm{Si}$ isotope composition of the parent basalt $(-0.29 \pm 0.06 \%, 2 \mathrm{SD})$ is consistent with previously published values for basalts (BHVO-2 $=-0.31 \pm 0.06 \%$, 2SD; e.g., Abraham et al., 2008), and with the overall rather uniform $\delta^{30} \mathrm{Si}$ composition of terrestrial basalts (Savage et al., 2010; Fig. 5b). The Si isotope composition of bulk soils (ranging from -1.32 to $-0.38 \%$ ) and clay fractions (ranging from -2.04 to $-0.63 \%$ ) are within the range of previously reported $\mathrm{Si}$ isotope values for such materials (review in Opfergelt and Delmelle, 2012; Frings et al., 2016; Poitrasson, 2017; Fig. 5b). The evolution of the $\mathrm{Si}$ isotope compositions of soils and clay fractions towards lighter $\delta^{30} \mathrm{Si}$ values with increasing degree of weathering (Fig. 4a and b) is consistent with a preferential incorporation of light $\mathrm{Si}$ isotopes in secondary weathering phases, resulting in light $\delta^{30} \mathrm{Si}$ in soils and clay fractions relative to the parental basalt (e.g., Ziegler et al., 2005; Georg et al., 2009; Opfergelt and Delmelle, 2012). The relationship between the weathering degree and the bulk soil $\delta^{30} \mathrm{Si}$ is also supported by the heavier $\delta^{30} \mathrm{Si}$ of the HA horizon corresponding to a volcanic ash layer (HA redox, $67-83 \mathrm{~cm}$ depth $=-0.42 \pm 0.14 \%$ o, 2SD) close to the basalt $\delta^{30} \mathrm{Si}$ value, and to the heavier $\delta^{30} \mathrm{Si}$ of the $\mathrm{H} \mathrm{O} 4$ horizon located underneath a volcanic tephra layer $(\mathrm{H}$ tephra $40-52 \mathrm{~cm}$; Table EA-1) and potentially including a basaltic contribution ( $\mathrm{H} \mathrm{O} 4=-0.47 \pm 0.08 \%$, 2SD) (Fig. 4a).

The presence of Fe-oxides in the secondary clay fractions may contribute to the light $\mathrm{Si}$ isotope composition of those clay fractions, due to the $\mathrm{Si}$ adsorption onto Fe-oxides (Jones and Handreck, 1963; Swedlund and Webster, 1999; Hiemstra et al., 2007) favouring isotopically 
light Si (Delstanche et al., 2009; Opfergelt et al., 2009). However, the $\mathrm{Si}_{\mathrm{d}} / \mathrm{Si}_{\mathrm{t}}$ ratio, that can be used as a relative indicator of the contribution of $\mathrm{Si}$ adsorbed onto Fe-oxides to the total $\mathrm{Si}$ content in soils, suggests that the proportion of $\mathrm{Si}_{\mathrm{d}}$ in Icelandic soils is limited $\left(\mathrm{Si}_{\mathrm{d}} / \mathrm{Si}_{\mathrm{t}}\right.$ : $\mathrm{BA}-\mathrm{GA}=2.2 \pm 0.5 \% ; \mathrm{HA}=4.8 \pm 2.2 \% ; \mathrm{H}=5.2 \pm 3.3 \%$; Table 1). Even if the $\mathrm{Si}_{\mathrm{d}} / \mathrm{Si}_{\mathrm{t}}$ ratio is two times higher in $\mathrm{HA}$ than in BA-GA, the proportion of $\mathrm{Si}$ adsorbed is below $8 \%$, which is limited relative to $\mathrm{Si}$ mass in aluminosilicates. Consequently, the contribution of light $\mathrm{Si}$ isotopes adsorbed onto $\mathrm{Fe}$-oxides to the observed isotope difference between $\delta^{30} \mathrm{Si}_{\text {clay }}$ in $\mathrm{HA}(-1.67 \pm 0.35 \%$, 2SD $)$ and in BA-GA $(-0.98 \pm 0.24 \%$, $2 \mathrm{SD}$; Table 1$)$ is probably limited.

In secondary aluminosilicates, there is an evolution from poorly crystalline aluminosilicates such as allophane forming in poorly weathered soils V-BA-GA (as supported by higher $\mathrm{Si}_{\mathrm{o}}$ content than in HA-H; Table 1), towards crystalline aluminosilicates such as kaolinite in more weathered soils HA-H. That evolution is generally accompanied by a decrease of the $\delta^{30} \mathrm{Si}$ value of the clay minerals (e.g., Ziegler et al., 2005; Opfergelt et al., 2012; Cornelis et al., $2014)$, in good agreement with the decrease in $\delta^{30} \mathrm{Si}_{\text {clay }}$ from BA-GA to HA (Fig. 3b).

In organic-rich soils, such as HA-H (Table 1), the affinity of Al for organic ligands at relatively low $\mathrm{pH}$ limits $\mathrm{Al}$ availability for the formation of allophane (Parfitt and Kimble, 1989; Mizota and van Reeuwijk, 1989; Parfitt, 2009). These conditions, combined with the enhanced dissolution of glass at lower $\mathrm{pH}$ (Oelkers and Gislason, 2001), favour the increase of the $\mathrm{Si}$ concentration in solution (Fig. EA-4b). During periods of freezing, Si supersaturation with respect to amorphous silica may be reached, leading to amorphous silica precipitation (Shoji and Masui, 1971; Ping et al., 1988; Dietzel, 2005). The occurrence of amorphous silica is confirmed by XRD for the HA-H soils and is not observed in the V-BA-GA soils (Fig. EA-2). The light isotopes of $\mathrm{Si}$ are known to be preferentially incorporated into amorphous Si (e.g., Li et al., 1995; Geilert et al., 2014, 2015; Roerdink et al., 2015; Oelze et al., 2015), which may contribute to the lighter $\mathrm{Si}$ isotope compositions of the HA and $\mathrm{H}$ bulk soils relative to the V-BA-GA soils (Fig. 4a). A contribution from phytoliths to the fraction of amorphous $\mathrm{Si}$ in soils cannot be ruled out (McKeague and Cline, 1963), but is unlikely to represent the only contribution to amorphous silica. To be detected by XRD, an amorphous phase needs to represent $\sim 30 \%$ of the sample (e.g., Paque et al., 2016). Taking the Si content in plants (25 $\mathrm{g} \mathrm{kg}^{-1}$; Opfergelt et al., 2014) and the amount of organic carbon in $\mathrm{HA}$ and $\mathrm{H}$ soils (between 18\% and $42 \%$; Table 1), a minimum $\mathrm{Si}$ contribution from organic matter in soils would be $\sim 1 \%$ (considering a low organic matter decomposition), and that contribution alone would not be detected by XRD. The presence of phytoliths may contribute to the $\mathrm{Si}$ isotope variability in bulk soils but is unlikely to explain the lighter $\delta^{30} \mathrm{Si}$ in $\mathrm{HA}-\mathrm{H}$ soils relative to the other soils because plants preferentially incorporate the light Si isotopes (e.g., Opfergelt and Delmelle, 2012 and references therein) from soil solutions that are heavier than the bulk soil (Fig. 4c). The presence of amorphous silica in HA-H and not in V-BA-GA supports the limited availability of $\mathrm{Al}$ to form alumino-silicates in HA-H relative to V-BA-GA, and provides indirect support for the formation of metal-organic complexes in $\mathrm{HA}-\mathrm{H}$, as suggested in Section 4.2. The formation of metal-organic complexes involving $\mathrm{Al}$ in $\mathrm{HA}-\mathrm{H}$ is confirmed by the higher proportion of pyrophosphate extractable $\mathrm{Al}\left(\mathrm{Al}_{\mathrm{p}} / \mathrm{Al}_{\mathrm{t}}\right.$, used to estimate metal complexes with organic ligands; Fig. EA-1c) in HA-H than in BA-GA.

Heavier $\delta^{30} \mathrm{Si}$ compositions in soil solutions (ranging from -0.19 to $+1.22 \%$ in BA-GA-HA-H) relative to the basalt result from the preferential incorporation of light $\mathrm{Si}$ isotopes in secondary weathering phases (e.g., Ziegler et al., 2005; Georg et al., 2009; Opfergelt and Delmelle, 2012; Fig. 5b). The Si isotope difference between the soil and the soil solution is within the same range in BA-GA and HA-H $\left(\Delta^{30} \mathrm{Si}_{\text {solution-soil }}=0.92 \pm 0.26 \%\right.$ oxcept in $\mathrm{H}$ soil profile below $50 \mathrm{~cm}$ where the soil solutions are heavier than any other soil solutions (for $\mathrm{H} \mathrm{O} 4$ and $\mathrm{H} \mathrm{O} 6$ solutions: $\Delta^{30} \mathrm{Si}_{\text {solution-soil }}=1.63 \pm 0.40 \%$; Fig. 6 ; Fig. $4 \mathrm{c}$; Fig. EA-4a). These data do not suggest a contribution from the dissolution of secondary minerals in HA-H organic rich-soils more acidic, as it would release light $\mathrm{Si}$ isotopes in solution (Cornelis et al., 2010; Steinhoefel et al., 2017). No specific process is reported to release of heavy $\mathrm{Si}$ isotopes in solution. Instead, successive mineral precipitation with the preferential incorporation of light $\mathrm{Si}$ isotopes may lead to a larger $\mathrm{Si}$ isotope fractionation between the soil and the soil solution. Successive precipitation of amorphous $\mathrm{Si}$ and clay minerals has been suggested in HA-H and not in BA-GA (Opfergelt et al., 2011). The heavier $\delta^{30} \mathrm{Si}$ in $\mathrm{H}$ solutions relative to other soil solutions support that the precipitation of amorphous silica occurs in addition to the formation of secondary clay minerals. This is consistent with a limited availability of $\mathrm{Al}$ in $\mathrm{H}$ when metal-organic complexes are formed, as highlighted based on Fe isotopes (Section 4.2; Figs. EA-5a and 5b).

\subsection{Implications for the Fe export to rivers}

Based on the present study, it can be anticipated that if warming peatland at high latitudes (Romanovsky et al., 2010; IPCC, 2013) decreases soil drainage and leads to more anoxic soils, Fe export from soils as Fe-organic complexes will increase. Although beyond the scope of the present study, the potential implications for Fe in rivers can be considered based on the few Fe isotope compositions measured for Icelandic rivers from the catchment areas in which the soil profiles are located in (Table 3). The riverine $\mathrm{Fe}$ isotope compositions of the dissolved fraction $(<0.2 \mu \mathrm{m}$; $\delta^{57} \mathrm{Fe}=-0.55 \pm 0.30 \%$ o, 2SD, $\left.n=3\right)$ are within the range of $\delta^{57} \mathrm{Fe}$ values reported for the dissolved fraction of other rivers (e.g., -1 to 0\%; Bergquist and Boyle, 2006; Mulholland et al., 2015; Fig. 5a). The dissolved Fe fraction of rivers $(<0.2 \mu \mathrm{m})$ includes truly dissolved $\mathrm{Fe}(<10 \mathrm{kD})$ and a range of colloidal $\mathrm{Fe}(10 \mathrm{kD}-0.2 \mu \mathrm{m})$. The colloidal fraction of the $\mathrm{A} 4$ river locality $(10 \mathrm{kD}-0.2 \mu \mathrm{m})$ is heavier $(-0.14 \pm 0.07 \%, 2 \mathrm{SD})$ than the corresponding dissolved fraction $(<0.2 \mu \mathrm{m} ;-0.46 \pm 0.07 \%$, $2 \mathrm{SD})$. Based on an isotope mass balance calculation where $26 \%$ of $\mathrm{Fe}$ has been measured in the colloidal fraction (Table 3), the $\delta^{57} \mathrm{Fe}$ value 
of the truly dissolved $\mathrm{Fe}$ is $-0.57 \%$, suggesting that the colloidal riverine $\mathrm{Fe}$ fraction represents an isotopically heavier $\mathrm{Fe}$ carrier than the truly dissolved Fe. This observation is consistent with the heavier $\delta^{57} \mathrm{Fe}$ values reported for river colloids (Ingri et al., 2006; Ilina et al., 2013; Akerman et al., 2014; Escoube et al., 2015; Mulholland et al., 2015; Fig. 5a) relative to the dissolved fraction of global rivers (e.g., Bergquist and Boyle, 2006).

The heavier $\delta^{57} \mathrm{Fe}$ value of the colloidal fraction $(10 \mathrm{kD}$ $-0.2 \mu \mathrm{m})$ relative to the dissolved fraction $(<0.2 \mu \mathrm{m})$ of a local Icelandic river may reflect a contribution from colloidal $\mathrm{Fe}$ originating in soils. Colloidal $\mathrm{Fe}$ exported from soils may be present as $\mathrm{Fe}$ oxyhydroxide nanoparticulates and/or Fe-organic complexes (Thompson et al., 2011). In the context of organic-rich soils, the contribution of Feorganic complexes transported from soils (Chauvel et al., 1987; Lucas et al., 1987; Fritsch et al., 2009, 2011) to rivers is thought to explain the heavy $\delta^{57} \mathrm{Fe}$ ratio of the dissolved fraction of the Rio Negro river relative to the dissolved fraction of the Amazon river, Brazil (Bergquist and Boyle, 2006; dos Santos Pinheiro et al., 2014). In Iceland, the available $\delta^{57} \mathrm{Fe}$ data for $\mathrm{H}$ soil solutions suggests that the release of colloidal Fe from Histosols may contribute to the colloidal heavy $\delta^{57} \mathrm{Fe}$ of rivers draining peat soils. Further study is required to quantify the contribution from $\mathrm{Fe}$ oxyhydroxides nanoparticules and/or Fe-organic complexes to the colloids exported from soils to rivers, and hence the impact for Fe transport in rivers.

\section{CONCLUSIONS}

The Fe isotope composition in Icelandic soils provides important insights into the processes controlling $\mathrm{Fe}$ export from high latitude soils as function of weathering and drainage (Fig. 6). During early weathering stages, well-drained soils do not generate any significant $\delta^{57} \mathrm{Fe}$ isotope variability in the bulk soils $(0.09 \pm 0.08 \%$ o, $2 \mathrm{SD})$ relative to the $\delta^{57} \mathrm{Fe}$ composition of the parent basalt $(0.07 \pm 0.04 \%$, 2SD). In contrast, in poorly drained soils that have experienced a higher degree of weathering, light Fe isotopes are released in solution by reductive or ligand-controlled mineral dissolution. The Fe released is either quantitatively precipitated in Fe-oxides, where the fluctuating redox conditions can account for the lighter $\delta^{57} \mathrm{Fe}$ in soils $(-0.14 \pm 0.33 \%$ o, 2SD) than in the basalt and increasingly lighter $\delta^{57} \mathrm{Fe}$ in soils with increasing amount of Fe-oxides, or else leached from soils under anoxic conditions leaving heavier $\delta^{57} \mathrm{Fe}$ in soils $(0.34 \pm 0.26 \%$, 2SD $)$ than in the basalt. In soil solutions, a limited $\mathrm{Fe}$ isotope fractionation in poorly weathered well-drained soils $\left(\Delta^{57} \mathrm{Fe}_{\text {solution-soil }}=-0.11 \pm 0.12 \%\right.$ ) reflects proton-promoted mineral dissolution (Fig. 6). Larger Fe isotope fractionation in more weathered poorly drained soils $\left(\Delta^{57} \mathrm{Fe}_{\text {solution-soil }}=\right.$ $-0.41 \pm 0.32 \%$ ) reflects the presence of $\mathrm{Fe}$ mobilised by reductive mineral dissolution and ligand-controlled dissolution, and suggests the formation of Fe-organic complexes in solution under anoxic conditions (Fig. 6).

The $\delta^{30} \mathrm{Si}$ in soils (ranging from -1.32 to $-0.38 \%$ ) decreases relative to the parent basalt $(-0.29 \pm 0.06 \%$, 2SD) with increasing degree of weathering and the forma- tion of secondary aluminosilicates, and more specifically with the evolution from poorly crystalline aluminosilicates such as allophane to crystalline clay minerals such as kaolinite. Under oxic conditions and in fluctuating redox conditions, the heavier $\delta^{30} \mathrm{Si}$ composition of soil solutions than soils $\left(\Delta^{30} \mathrm{Si}_{\text {solution-soil }}=0.92 \pm 0.26 \%\right.$ o $)$ reflects the incorporation of light $\mathrm{Si}$ isotopes into secondary aluminosilicates. Under anoxic conditions, a larger $\Delta^{30} \mathrm{Si}_{\text {solution-soil }}$ $(1.63 \pm 0.40 \%$ o points to a succession of processes that preferentially incorporates light $\mathrm{Si}$ isotopes, i.e., the cumulative contribution of secondary clay minerals and amorphous silica precipitation. The precipitation of amorphous silica is confirmed and suggests that $\mathrm{Si}$ concentration in solution reached supersaturation with respect to amorphous silica due to $\mathrm{Al}$ affinity for organic ligands, thereby providing indirect support for the formation of metalorganic complexes in the poorly drained soils consistently with the conclusion based on $\mathrm{Fe}$ isotopes.

This study suggests that if the warming of peatlands at high latitude decreases soil drainage, $\mathrm{Fe}$ export from soils as Fe-organic complexes will increase. Further study is needed to quantify the implications of such enhanced $\mathrm{Fe}$ export from soils on the proportion of colloidal Fe in rivers and hence for Fe transport in rivers.

\section{ACKNOWLEDGMENTS}

We greatly thank A. Iserentant, C. Givron, A. Lannoye, P. Populaire, F. Van Hoye, W. Nguefack for their contribution on the soil characterisation, B. Sigfusson, P. Savage, R. Neely for their help on the field in Iceland, N. Belshaw, T. Krastev, F. Mokadem, A. Mason, S. Wyatt for their assistance in the isotope geochemistry lab, and S. Hammond for ICP-MS analyses. G. Nowell at Durham University is thanked for his invaluable help with Fe isotope analyses. The manuscript benefited from discussions with P. Delmelle, B. Delvaux, E. Maters, R. Ammar, M. Paque and D. Houben. We thank the Associate Editor, J. Wiederhold, and T. Bullen, A. Thompson and one anonymous reviewer for their very constructive comments. S.O. is funded by the "Fonds National de la Recherche Scientifique" (FNRS, Belgium, FC69480) and acknowledges a funding from FNRS (FRFC contract $\mathrm{n}^{\circ} 3762.4599 .11$ ) and from FSR (Fonds Special de Recherche 2008, ADRE86C5, UCL, Belgium). H.W. acknowledges an ERC Starting Grant ("HabitablePlanet", 306655) and NERC (UK) Advanced Fellowship (NE/F014295/1), which funded the Fe isotope measurements of this study. Funding for Si isotope analyses at Oxford was provided by an Advanced Fellowship to A.H. from the European Research Council.

\section{APPENDIX A. SUPPLEMENTARY MATERIAL}

Supplementary data associated with this article can be found, in the online version, at http://dx.doi.org/10.1016/ j.gca.2017.08.033.

\section{REFERENCES}

Abraham K., Opfergelt S., Fripiat F., Cavagna A.-J., de Jong J. T. M., Foley S., André L. and Cardinal D. (2008) $\Delta^{30} \mathrm{Si}$ and $\delta^{29} \mathrm{Si}$ determinations on USGS BHVO-1 and BHVO-2 reference materials via new configuration on $\mathrm{Nu}$ Plasma Multi Collector ICP-MS. Geost. Geoanal. Res. 32, 193-202. 
Akerman A., Poitrasson F., Oliva P., Audry S., Prunier J. and Braun J.-J. (2014) The isotopic fingerprint of Fe cycling in an equatorial soil-plant-water system: the Nsimi watershed, South Cameroon. Chem. Geol. 385, 104-116.

Arnalds O. (2004) Volcanic Soils of Iceland. Catena 56, 3-20.

Arnalds O. (2008) Soils of Iceland. Jokull 58, 409-421.

Arnalds O. and Gíslason S. R. (2002) Validity of oxalate extraction for characterization and $\mathrm{Al} / \mathrm{Si}$ calculations for vitric Andosols. Soil Resources of European Volcanic Systems. Mainzer Naturwiss. Archiv. 40, 13-15.

Arnalds O. and Gretarsson E. (2001) Soil Map of Iceland, second ed. Agricultural Research Institute, Reykjavik. Available in digital format www.rala.is/desert.

Arnalds O., Gudmundsson J., Oskarsson H., Brink S. H. and Gisladottir F. O. (2016) Icelandic inland wetlands: characteristics and Extent of Draining. Wetlands. http://dx.doi.org/ 10.1007/s13157-016-0784-1.

Bascomb D. L. (1968) Distribution of pyrophosphate extractable iron and organic carbon in soils in various groups. J. Soil. Sci. 19, 251-268.

Beard B. L., Johnson C. M., Skulan J. L., Nealson K. H., Cox L. and Sun H. (2003) Application of Fe isotopes to tracing the geochemical and biological cycling of Fe. Chem. Geol. 195, 87117.

Bergquist B. A. and Boyle E. A. (2006) Iron isotopes in the Amazon River system: weathering and transport signatures. Earth Planet. Sci. Lett. 248, 54-68.

Blakemore, L.C., Searle, P.L., Daly, B.K., 1981. Methods for Chemical Analysis of Soil. New Zealand Soil Bureau Scientific Report $10 \mathrm{~A}$, second revision.

Bonneville S., Van Cappellen P. and Behrends T. (2004) Microbial reduction of iron(III) oxyhydroxides: effects of mineral solubility and availability. Chem. Geol. 212, 255-268.

Borggaard, O.K., 1988. Phase Identification by Selective Dissolution Techniques. Iron in soils and clay minerals. In: Stucki, J. W., Goodman, B.A., Schwertmann, U. (Eds.), Nato Science Series C, vol. 217, pp. 83-98.

Boyd P. W., Watson A. J., Law C. S., Abraham E. R., Trull T. and Murdoch R., et al. (2000) A mesoscale phytoplankton bloom in the polar Southern Ocean stimulated by iron fertilization. Nature 407, 695-702.

Boyle E. A. and Edmond J. M. (1977) The mechanism of iron removal in estuaries. Geochim. Cosmochim. Acta 41, 1313-1324.

Brantley S. L., Liermann L. and Bullen T. D. (2001) Fractionation of $\mathrm{Fe}$ isotopes by soil microbes and organic acids. Geology 29, $535-538$.

Brantley S. L., Liermann L. J., Guynn R. L., Anbar A., Icopini G. A. and Barling J. (2004) Fe isotopic fractionation during mineral dissolution with and without bacteria. Geochim. Cosmochim. Acta 68, 3189-3204.

Buettner S. W., Kramer M. G., Chadwick O. A. and Thompson A. (2014) Mobilization of colloidal carbon during iron reduction in basaltic soils. Geoderma 221-222, 139-145.

Buss H. L., Mathur R., White A. F. and Brantley S. L. (2010) Phosphorus and iron cycling in deep saprolite, Luquillo Mountains, Puerto Rico. Chem. Geol. 269, 52-61.

Caldelas C. and Weiss D. J. (2017) Zinc Homeostasis and isotopic fractionation in plants: a review. Plant Soil 411, 17-46.

Chapman J. B., Weiss D. J., Shan Y. and Lemburger M. (2009) Iron isotope fractionation during leaching of granite and basalt by hydrochloric and oxalic acids. Geochim. Cosmochim. Acta 73, 1312-1324.

Chauvel A., Lucas Y. and Boulet R. (1987) On the genesis of the soil mantle of the region of Manaus, Central Amazonia, Brazil. Experientia 43, 234-241.
Chorover J., Kretzschmar R., Garcia-Pichel F. and Sparks D. L. (2007) Soil biogeochemical processes within the Critical Zone. Elements 3, 321-326.

Cornelis J.-T., Delvaux B., Cardinal D., André L., Ranger J. and Opfergelt S. (2010) Tracing mechanisms controlling the release of dissolved silicon in forest soil solutions using $\mathrm{Si}$ isotopes and Ge/Si ratios. Geochim. Cosmochim. Acta 74, 3913-3924.

Cornelis J. T., Weis D., Lavkulich L., Vermeire M.-L., Delvaux B. and Barling J. (2014) Silicon isotopes record dissolution and reprecipitation of pedogenic clay minerals in a podzolic soil chronosequence. Geoderma 235-236, 19-29.

Cornell R. M. and Schwertmann U. (2003) The Iron Oxides: Structure, Properties, Reactions, Occurrence and Uses, second ed. VCH, Weinheim, Germany.

Cornu S., Besnault A. and Bermond A. (2008) Soil podzolisation induced by reforestation as shown by sequential and kinetic extractions of Fe and Al. Eur. J. Soil Sci. 59, 222-232.

Cornu S. and Clozel B. (2000) Extractions séquentielles et spéciation des éléments trace métalliques dans les sols naturels: analyse critique. Etudes et Gestion des Sols 7, 179-189.

Crochet P., Jóhannesson T., Jónsson T., Sigurðsson O., Björnsson H., Pálsson F. and Barstad I. (2007) Estimating the spatial distribution of precipitation in Iceland using a linear model of orographic precipitation. J. Hydrometeorol. 8, 1285-1306.

Dauphas N., John G. J. and Rouxel O. (2017) Iron isotope systematics. Rev. Mineral. Geochem. 82, 415-510.

Delmelle P., Opfergelt S., Cornelis J.-T. and Ping C. L. (2015) Volcanic soils. In The Encyclopedia of Volcanoes (eds. H. Sigurdsson, B. Houghton, H. Rymer, J. Stix and S. McNutt), second ed. Academic Press, San Diego, pp. 1253-1264.

Delstanche S., Opfergelt S., Cardinal D., Elsass F., André L. and Delvaux B. (2009) Silicon isotopic fractionation during adsorption of aqueous monosilicic acid onto iron oxide. Geochim. Cosmochim. Acta 73, 923-934.

Dideriksen K., Baker J. A. and Stipp S. L. S. (2008) Equilibrium Fe isotope fractionation between inorganic aqueous $\mathrm{Fe}(\mathrm{III})$ and the siderophore complex, Fe(III)-desferrioxamine B. Earth Planet. Sci. Lett. 269, 280-290.

Dietzel M. (2005) Impact of cyclic freezing on precipitation of silica in $\mathrm{Me}-\mathrm{SiO}_{2}-\mathrm{H}_{2} \mathrm{O}$ systems and geochemical implications for cryosoils. Chem. Geol. 216, 79-88.

dos Santos Pinheiro G. M., Poitrasson F., Sondag F., Cochonneau G. and Vieira L. C. (2014) Contrasting iron isotopic compositions in river suspended particulate matter: the Negro and the Amazon annual river cycles. Earth Planet. Sci. Lett. 394, 168 178.

Emmanuel S., Erel Y., Matthews A. and Teutsch N. (2005) A preliminary mixing model for $\mathrm{Fe}$ isotopes in soils. Chem. Geol. 222, 23-34.

Escoube R., Rouxel O. J., Pokrovsky O. S., Schroth A., Holmes R. M. and Donard O. F. X. (2015) Iron isotope systematics in Arctic rivers. C. R. Geosci. 347, 377-385.

Fantle M. S. and DePaolo D. J. (2004) Iron isotopic fractionation during continental weathering. Earth Planet. Sci. Lett. 228, $547-562$

Fekiacova Z., Pichat S., Cornu S. and Balesdent J. (2013) Inferences from the vertical distribution of $\mathrm{Fe}$ isotopic compositions on pedogenetic processes in soils. Geoderma 209-210, 110-118.

Fekiacova Z., Vermeire M. L., Bechon L., Cornelis J. T. and Cornu S. (2017) Can $\mathrm{Fe}$ isotope fractionations trace the pedogeneticmechanisms involved in podzolization? Geoderma 296, 38-46.

Frings P. J., Clymans W., Fontorbe G., De La Rocha C. L. and Conley D. J. (2016) The continental Si cycle and its impact on the ocean Si isotope budget. Chem. Geol. 425, 12-36. 
Fritsch E., Allard T., Benedetti M. F., Bardy M., Do Nascimento N. R., Li Y. and Calas G. (2009) Organic complexation and translocation of ferric iron in podzols of the Negro River watershed. Separation of secondary Fe species from Al species. Geochim. Cosmochim. Acta 73, 1813-1825.

Fritsch E., Balan E., Do Nascimento N. R., Allard T., Bardy M., Bueno G., Derenne S., Melfi A. J. and Calas G. (2011) Deciphering the weathering processes using environmental mineralogy and geochemistry: towards an integrated model of laterite and podzol genesis in the Upper Amazon Basin. C. R. Geosci. 343, 188-198.

Garnier J., Garnier J.-M., Vieira C. L., Akerman A., Chmeleff J., Ruiz R. I. and Poitrasson F. (2017) Iron isotope fingerprints of redox and biogeochemical cycling in the soil-water-rice plant system of a paddy field. Sci. Tot. Environ. 574, 1622-1632.

Geilert S., Vroon P. Z., Roerdink D. L., Cappellen P. V. and van Bergen M. J. (2014) Silicon isotope fractionation during abiotic silica precipitation at low temperatures: inferences from flowthrough experiments. Geochim. Cosmochim. Acta 142, 95-114.

Geilert S., Vroon P. Z., Keller N. S., Gudbrandsson S., Stefánsson A. and van Bergen M. J. (2015) Silicon isotope fractionation during silica precipitation from hot-spring waters: evidence from the Geysir geothermal field, Iceland. Geochim. Cosmochim. Acta 164, 403-427.

Georg R. B., Reynolds B. C., Frank M. and Halliday A. N. (2006) New sample preparation techniques for the determination of $\mathrm{Si}$ isotopic compositions using MC-ICPMS. Chem. Geol. 235, 95104.

Georg R. B., Zhu C., Reynolds B. C. and Halliday A. N. (2009) Stable silicon isotopes of groundwater, feldspars, and clay coatings in the Navajo Sandstone aquifer, Black Mesa, Arizona, USA. Geochim. Cosmochim. Acta 73, 2229-2241.

Guelke M. and von Blanckenburg F. (2007) Fractionation of stable iron isotopes in higher plants. Environ. Sci. Technol. 41, 18961901.

Guelke M., von Blanckenburg F., Schoenberg R., Staubwasser M. and Stuetzel H. (2010) Determining the stable Fe isotope signature of plant-available iron in soils. Chem. Geol. 277, 269280 .

Guelke-Stelling M. and von Blanckenburg F. (2012) Fe isotope fractionation caused by translocation of iron during growth of bean and oat as models of strategy I and II plants. Plant Soil 352, 217-223.

Guicharnaud R. A. (2009) Biogeochemistry of Icelandic Andosols Ph.D. thesis. University of Aberdeen, Aberdeen, UK, p. 140.

Hecht B. P., Vogt K. A., Eysteinsson P. and Vogt D. J. (2007) Changes in air and soil temperatures in three Icelandic birch forests with different land-use histories. Icel. Agric. Sci. 20, 4960.

Henkel S., Kasten S., Poulton S. W. and Staubwasser M. (2016) Determination of the stable iron isotopic composition of sequentially leached iron phases in marine sediments. Chem. Geol. 421, 93-102.

Herbillon, A.J., 1986. Chemical estimation of weatherable minerals present in the diagnostic horizons of low activity clay soils. In: Beinroth, F.H., Camargo, M.N., Eswaran (Eds.), Proceedings of the 8th International Soil Classification Workshop: Classification, Characterization and Utilization of Oxisols, Part 1. EMBRAPA, Rio de Janeiro, pp. 39-48.

Hiemstra T., Barnett M. O. and van Riemsdijk W. H. (2007) Interaction of silicic acid with goethite. J. Colloid Interface Sci. 310, 8-17.

Ilina S. M., Poitrasson F., Lapitskiy S. A., Alekhin Y. V., Viers J. and Pokrovsky O. S. (2013) Extreme iron isotope fractionation between colloids and particles of boreal and temperate organicrich waters. Geochim. Cosmochim. Acta 101, 96-111.
Ingri J., Malinovskiy D., Rodushkin I., Baxter D., Widerlund A., Andersson P., Gustafsson O. and Forsling W. (2006) Iron isotope fractionation in river colloidal matter. Earth Planet. Sci. Lett. 245, 792-798.

IPCC, 2013. Climate Change 2013: The Physical Science Basis. In: Stocker, T.F. et al. (Eds.), Contribution of Working Group I to the Fifth Assessment Report of the Intergovernmental Panel on Climate Change. Cambridge University Press, 1535 pp.

IUSS Working Group WRB, 2014. World Reference Base for Soil Resources 2014. International soil classification system for naming soils and creating legends for soil maps. FAO, Rome.

Jeanroy E. and Guillet B. (1981) The occurence of suspended ferruginous particles in pyrophosphate extracts of some soil horizons. Geodema 26, 95-105.

Johannesson T., Eiriksson T., Gudmundsdottir K. B., Sigurdarson S. and Kristinsson J. (2007) Overview: Seven trace elements in Icelandic forage. Their value in animal health and with special relation to scrapie. Icel. Agric. Sci. 20, 3-24.

Johnson C. M., Skulan J. L. and Beard B. L., et al. (2002) Isotopic fractionation between $\mathrm{Fe}(\mathrm{III})$ and $\mathrm{Fe}$ (II) in aqueous solutions. Earth Planet. Sci. Lett. 195, 141-153.

Johnson C. M., Beard B. L. and Roden E. E. (2008) The iron isotope fingerprints of redox and biogeochemical cycling in modern and ancient earth. Annu. Rev. Earth Planet. Sci. 36, 457-493.

Jones L. H. P. and Handreck K. A. (1963) Effects of iron and aluminium oxides on silica in solution in soils. Nature 198, 852 853.

Kiczka M., Wiederhold J. G., Frommer J., Kraemer S. M., Bourdon B. and Kretzschmar R. (2010a) Iron isotope fractionation during proton- and ligand-promoted dissolution of primary phyllosilicates. Geochim. Cosmochim. Acta 74, 31123128.

Kiczka M., Wiederhold J. G., Frommer J., Kraemer S. M., Bourdon B. and Kretzschmar R. (2010b) Iron isotope fractionation during $\mathrm{Fe}$ uptake and translocation in alpine plants. Environ. Sci. Technol. 44, 6144-6150.

Kiczka M., Wiederhold J. G., Frommer J., Voegelin A., Kraemer S. M., Bourdon B. and Kretzschmar R. (2011) Iron speciation and isotope fractionation during silicate weathering and soil formation in an alpine glacier forefield chronosequence. Geochim. Cosmochim. Acta 75, 5559-5573.

Kostka J. E. and Luther G. W. (1994) Partitioning and speciation of solid phase iron in saltmarsh sediments. Geochim. Cosmochim. Acta 58, 1701-1710.

Krachler R., Jirsa F. and Ayromlou S. (2005) Factors influencing the dissolved iron input by river water to the open ocean. Biogeosciences 2, 311-315.

Krachler R., Krachler R. F., von der Kammer F., Süphandag A., Jirsa F., Ayromlou S., Hofmann T. and Keppler B. K. (2010) Relevance of peat-draining rivers for the riverine input of dissolved iron into the ocean. Sci. Total Environ. 408, 24022408.

Li Y., Ding T. P. and Wan D. (1995) Experimental study of silicon isotope dynamic fractionation and its application in geology. Chin. J. Geochem. 14, 212-219.

Liu S. A., Teng F. Z., Li S., Wei G. J., Ma J. L. and Li D. (2014) Copper and iron isotope fractionation during weathering and pedogenesis: Insights from saprolite profiles. Geochim. Cosmochim. Acta 146, 59-75.

Lucas Y., Boulet R., Chauvel A. and Veillon L. (1987) Systèmes sols ferrallitiques - Podzols en région amazonienne. In Podzols et Podzolisation (eds. D. Righi and A. Chauvel). AFES et INRA, Plaisir et Paris, pp. 53-65.

Mansfeldt T., Schuth S., Häusler W., Wagner F., Kaufhold S. and Overesch M. (2012) Iron oxide mineralogy and stable iron 
isotope composition in a Gleysol with petrogleyic properties. $J$. Soil Sedim.: Protection, Risk Assessment, \& Remediation 12, 97114.

Marschner H. and Römheld V. (1994) Strategies of plants for acquisition of iron. Plant Soil 165, 261-274.

Martin J. H. and Fitzwater S. E. (1988) Iron-deficiency limits phytoplankton growth in the Northeast Pacific Subarctic. Nature 331, 341-342.

McKeague J. A. and Cline M. G. (1963) Silica in soils. Adv. Agron. 15, 339-396.

Mehra, O.P., Jackson, M.L., 1960. Iron oxides removal from soils and clays by dithionite-citrate system buffered with sodium bicarbonate. In: Proc. 7th Natl. Conf. Clays Clay Minerals, Washington, pp. 317-327.

Melton E. D., Swanner E. D., Behrens S., Schmidt C. and Kappler A. (2014) The interplay of microbially mediated and abiotic reactions in the biogeochemical Fe cycle. Nat. Rev. Microbiol. 12, 797-808.

Millet M.-A., Baker J. A. and Payne C. E. (2012) Ultra-precise stable Fe isotope measurements by high resolution multiplecollector inductively coupled plasma mass spectrometry with a 57Fe-58Fe double spike. Chem. Geol. 304, 18-25.

Mizota, C., van Reeuwijk, L.P., 1989. Clay Mineralogy and Chemistry of Soils Formed in Volcanic Material in Diverse Climatic Regions. Soil Monograph 2. ISRIC, Wageningen.

Morel F. M. M., Rueter J. G. and Price N. M. (1991) Iron nutrition of phytoplankton and its possible importance in the ecology of ocean regions with high nutrient and low biomass. Oceanography 4, 56-61.

Morgan J. L., Wasylenki L. E., Nuester J. and Anbar A. D. (2010) $\mathrm{Fe}$ isotope fractionation during equilibration of Fe-organic complexes. Environ. Sci. Technol. 44, 6095-6101.

Mulholland D. S., Poitrasson F., Boaventura G. R., Allard T., Vieira L. C., Santos R. V., Mancini L. and Seyler P. (2015) Insights into iron sources and pathways in the Amazon River provided by isotopic and spectroscopic studies. Geochim. Cosmochim. Acta 150, 142-159.

Oelkers E. H. and Gislason S. R. (2001) The mechanism, rates and consequences of basaltic glass dissolution. I: An experimental study of the dissolution rates of basaltic glass as a function of aqueous $\mathrm{Al}, \mathrm{Si}$ and oxalic acid concentration at $25^{\circ} \mathrm{C}$ and $\mathrm{pH}=3$ and 11. Geochim. Cosmochim. Acta 65, 3671-3681.

Oelze M., von Blanckenburg F., Hoellen D., Dietzel M. and Bouchez J. (2014) Si stable isotope fractionation during adsorption and the competition between kinetic and equilibrium isotope fractionation: implications for weathering systems. Chem. Geol. 380, 161-171.

Oelze M., von Blanckenburg F., Bouchez J., Hoellen D. and Dietzel M. (2015) The effect of Al on Si isotope fractionation investigated by silica precipitation experiments. Chem. Geol. 397, 94-105.

Opfergelt S., de Bournonville G., Cardinal D., André L., Delstanche S. and Delvaux B. (2009) Impact of soil weathering degree on silicon isotopic fractionation during adsorption onto iron oxides in basaltic ash soils, Cameroon. Geochim. Cosmochim. Acta 73, 7226-7240.

Opfergelt S., Cardinal D., André L., Delvigne C., Bremond L. and Delvaux B. (2010) Variations of $\delta^{30} \mathrm{Si}$ and $\mathrm{Ge} / \mathrm{Si}$ with weathering and biogenic input in tropical basaltic ash soils under monoculture. Geochim. Cosmochim. Acta 74, 225-240.

Opfergelt S., Burton K. W., Georg R. B., West A. J., Guicharnaud R., Sigfusson B., Siebert C., Gislason S. R. and Halliday A. N. (2014) Magnesium retention on the soil exchange complex controlling $\mathrm{Mg}$ isotope variations in soils, soil solutions and vegetation in volcanic soils, Iceland. Geochim. Cosmochim. Acta $125,110-130$.
Opfergelt S. and Delmelle P. (2012) Silicon isotopes and continental weathering processes: assessing controls on Si transfer to the ocean. C. R. Geosci. 344, 723-738.

Opfergelt S., Georg R. B., Burton K. W., Guicharnaud R., Siebert C., Gislason S. R. and Halliday A. N. (2011) Silicon isotopes in allophane as a proxy for mineral formation in volcanic soils. Applied Geochem. 26, S115-S118.

Opfergelt S., Georg R. B., Delvaux B., Cabidoche Y. M., Burton K. W. and Halliday A. N. (2012) Silicon isotopes and the tracing of desilication in volcanic soil weathering sequences, Guadeloupe. Chem. Geol. 326-327, 113-122.

Opfergelt S., Cornelis J. T., Houben D., Givron C., Burton K. W. and Mattielli N. (2017) The influence of weathering and soil organic matter on $\mathrm{Zn}$ isotopes in soils. Chem. Geol. 466, 140148.

Orradottir B., Archer S. R., Arnalds O., Wilding L. P. and Thurow T. L. (2008) Infiltration in Icelandic Andisols: the role of vegetation and soil frost. Arc. Antarc. Alp. Res. 40, 412-421.

Paque M., Detienne M., Maters E. C. and Delmelle P. (2016) Smectites and zeolites in ash from the 2010 summit eruption of Eyjafjallajökull volcano, Iceland. Bull Volcanol. 78, 61.

Parfitt R. L. (2009) Allophane and imogolite: role in soil biogeochemical processes. Clay Miner. 44, 135-155.

Parfitt R. L. and Childs C. W. (1988) Estimation of forms of Fe and $\mathrm{Al}$ - a review, and analysis of contrasting soils by dissolution and Mossbauer methods. Aust. J. Soil Res. 26, 121-144.

Parfitt R. L. and Kimble J. M. (1989) Conditions for formation of allophane in soils. Soil Sci. Soc. Am. J. 53, 971-977.

Pearce C. R., Burton K. W., Pogge von Strandmann P. A. E., James R. H. and Gislason S. R. (2010) Molybdenum isotope behaviour accompanying continental weathering and riverine transport in a basaltic terrain. Earth Planet. Sci. Lett. 295, 104 114.

Ping C. L., Shoji S. and Ito T. (1988) Properties and classification of three volcanic ash derived pedons from Aleutian Islands and Alaska Peninsula, Alaska. Soil Sci. Soc. Am. J. 52, 455-462.

Pogge von Strandmann P. A. E., Burton K. W., James R. H., van Calsteren P., Gislason S. R. and Mokadem F. (2006) Riverine behaviour of uranium and lithium isotopes in an actively glaciated basaltic terrain. Earth Planet. Sci. Lett. 251, 134-147.

Pogge Von Strandmann P. A. E., Burton K. W., James R. H., Van Calsteren P., Gislason S. R. and Sigfusson B. (2008) The influence of weathering processes on riverine magnesium isotopes in a basaltic terrain. Earth Planet. Sci. Lett. 276, 187-197.

Poitrasson F. (2017) Silicon isotope geochemistry. Rev. Mineral. Geochem. 82, 289-344.

Poitrasson F., Viers J., Martin F. and Braun J.-J. (2008) Limited iron isotope variations in recent lateritic soils from Nsimi, Cameroon: implications for the global $\mathrm{Fe}$ geochemical cycle. Chem. Geol. 253, 54-63.

Poulton S. W. and Raiswell R. (2002) The low-temperature geochemical cycle of iron: from continental fluxes to marine sediment deposition. Am. J. Sci. 302, 774-805.

Rai D. and Kittrick J. A. (1989) Mineral equilibria and the soil system. In Minerals in Soil Environments (eds. J. Dixon and S. Weed). Soil Science Society of America, Madison, WI, USA, pp. 161-198.

Reynolds B. C., Aggarwal J., André L., Baxter D., Beucher C., Brzezinski M. A., Engström E., Georg R. B., Land M., Leng M. J., Opfergelt S., Rodushkin I., Sloane H. S., van den Boorn S. H. J. M., Vroon P. Z. and Cardinal D. (2007) An interlaboratory comparison of $\mathrm{Si}$ isotope reference materials. $J$. Anal. Atom. Spectrom. 22, 561-568. 
Roerdink D. L., van den Boorn S. H., Geilert S., Vroon P. Z. and van Bergen M. J. (2015) Experimental constraints on kinetic and equilibriumsilicon isotope fractionation during the formation of non-biogenic chert deposits. Chem. Geol. 402, 40-51.

Romanovsky V. E., Smith S. L. and Christiansen H. H. (2010) Permafrost thermal state in the polar Northern Hemisphere during the International Polar Year 2007-2009: a synthesis. Permafrost Periglac. Process. 21, 106-116.

Rouiller J., Burtin G. and Souchier B. (1972) La dispersion des sols dans l'analyse granulométrique. Méthode utilisant les résines échangeuses d'ions. ENSAIA Nancy 14, 194-205.

Ryan J. N. and Gschwend P. M. (1991) Extraction of Iron Oxides from Sediments Using Reductive Dissolution by Titanium(III). Clays Clay Min. 39, 509-518.

Savage P. S., Georg R. B., Armytage R. M. G., Williams H. M. and Halliday A. N. (2010) Silicon isotope homogeneity in the mantle. Earth Planet. Sci. Lett. 295, 139-146.

Schauble E. (2004) Applying stable isotope fractionation theory to new systems. Rev. Mineral. Geochem. 55, 65-111.

Schuth S., Hurrass J., Munker C. and Mansfeldt T. (2015) Redoxdependent fractionation of iron isotopes in suspensions of a groundwater-influenced soil. Chem. Geol. 392, 74-86.

Schulz M., Stonestrom D., Lawrence C., Bullen T., Fitzpatrick J., Kyker-Snowman E., Manning J. and Mnich M. (2016) Structured heterogeneity in a marine terrace chronosequence: upland mottling. Vadose Zone J. 15(2). http://dx.doi.org/10.2136/ vzj2015.07.0102.

Schuth S. and Mansfeldt T. (2015) Iron isotope composition of aqueous phases of a lowland environment. Environ. Chem. 13, 89-101.

Schwertmann U. (2008) Iron oxides. In Encyclopedia of Soil Science (ed. W. Chesworth). Springer, Dordrecht, the Netherlands, pp. 363-369.

Shoji S. and Masui J.-I. (1971) Opaline silica of recent volcanic ash soils in Japan. J. Soil Sci. 22, 101-108.

Siebert C., Pett-Ridge J., Opfergelt S., Guicharnaud R., Halliday A. N. and Burton K. W. (2015) Molybdenum isotope fractionation in soils: influence of redox conditions, organic matter, and atmospheric inputs. Geochim. Cosmochim. Acta $162,1-24$.

Sigfusson B., Gislason S. R. and Paton G. I. (2008) Pedogenesis and weathering rates of a Histic Andosol in Iceland: field and experimental soil solution study. Geoderma 144, 572-592.

Smetacek V., Klaas C., Strass V. H., Assmy P., Montresor M. and Cisewski B., et al. (2012) Deep carbon export from a Southern Ocean iron-fertilized diatom bloom. Nature 487, 313-319.

Steinhoefel G., Breuer J., von Blanckenburg F., Horn I. and Michael Sommer M. (2017) The dynamics of Si cycling during weathering in two small catchments in the Black Forest (Germany) traced by Si isotopes. Chem. Geol. 466, 389-402.

Swedlund P. J. and Webster J. G. (1999) Adsorption and polymerisation of silicic acid on ferrihydrite, and its effect on arsenic adsorption. Water Res. 33, 3413-3422.

Swindles G. T., Morris P. J., Mullan D., Watson E. J. and Turner T. E., et al. (2015) The long-term fate of permafrost peatlands under rapid climate warming. Sci. Rep. 5, 17951.

Thompson A., Ruiz J., Chadwick O. A., Titus M. and Chorover J. (2007) Rayleigh fractionation of iron isotopes during pedogenesis along a climate sequence of Hawaiian basalt. Chem. Geol. 238, 72-83.

Thompson A., Rancourt D. G., Chadwick O. A. and Chorover J. (2011) Iron solid-phase differentiation along a redox gradient in basaltic soils. Geochim. Cosmochim. Acta 75, 119-133.

Walker A. L. (1983) The Effects of Magnetite on Oxalate- and Dithionite-Extractable Iron, Soil Sci. Soc. Am. J. 47, 10221026.
Welch S. A., Beard B. L., Johnson C. M. and Braterman P. S. (2003) Kinetic and equilibrium $\mathrm{Fe}$ isotope fractionation between aqueous $\mathrm{Fe}(\mathrm{II})$ and $\mathrm{Fe}(\mathrm{III})$. Geochim. Cosmochim. Acta 67, 4231-4250.

Westermann S., Østby T., Gisnås K., Schuler T. V. and Etzelmüller B. (2015) A ground temperature map of the North Atlantic permafrost region based on remote sensing and reanalysis data. The Cryosphere Disc. 9, 753-790.

Weyer S., Anbar A. D., Brey G. P., Munker C., Mezger K. and Woodland A. B. (2005) Iron isotope fractionation during planetary differentiation. Earth Planet. Sci. Lett. 240, 251-264.

Wiederhold J. G., Teutsch N., Kraemer S. M., Halliday A. N. and Kretzschmar R. (2007a) Iron isotope fractionation during pedogenesis in redoximorphic soils. Soil Sci. Soc. Am. J. 71, $1840-1850$.

Wiederhold J. G., Teutsch N., Kraemer S. M., Halliday A. N. and Kretzschmar R. (2007b) Iron isotope fractionation in oxic soils by mineral weathering and podzolisation. Geochim. Cosmochim. Acta 71, 5821-5833.

Wiederhold J. G., Kraemer S. M., Teutsch N., Borer P. M., Halliday A. N. and Kretzschmar R. (2006) Iron Isotope Fractionation during Proton-Promoted, Ligand-Controlled, and Reductive Dissolution of Goethite. Environ. Sci. Technol. 40, 3787-3793.

Williams H. M. and Bizimis M. (2014) Iron isotope tracing of mantle heterogeneity within the source regions of oceanic basalts. Earth Planet. Sci. Lett. 404, 396-407.

Williams H. M., Wood B. J., Wade J., Frost D. and Tuff J. (2012) Isotopic evidence for internal oxidation of the Earth's mantle. Earth Planet. Sci. Lett. 321-322, 54-63.

Wolff-Boenisch D., Gislason S. R. and Oelkers E. H. (2004) The effect of fluoride on the dissolution rates of natural glasses at $\mathrm{pH} 4$ and $25^{\circ} \mathrm{C}$. Geochim. Cosmochim. Acta 68, 4571-4582.

Wu L., Beard B. L., Roden E. E. and Johnson C. M. (2011) Stable iron isotope fractionation between aqueous $\mathrm{Fe}(\mathrm{II})$ and hydrous ferric oxide. Envi. Sci. Tech. 45, 1847-1852.

Yeghicheyan D., Carignan J., Valladon M., Bouhnik Le Coz M., Le Cornec F., Castrec-Rouelle M., Robert M., Aquilina L., Aubry E., Churlaud C., Dia A., Deberdt S., Dupré B., Freydier R., Gruau G., Hénin O., de Kersabiec A.-M., Macé J., Marin L., Morin N., Petitjean P. and Serrat E. (2001) A compilation of silicon and thirty one trace elements measured in the natural river water reference material SLRS-4 (NRC-CNRC). Geostand. Geoanal. Res. 25, 465-474.

Yesavage T. A., Fantle M. S., Vervoort J., Mathur R., Jin L., Liermann L. J. and Brantley S. L. (2012) Fe cycling in the Shale Hills Critical Zone Observatory, Pennsylvania: an analysis of biogeochemical weathering and $\mathrm{Fe}$ isotope fractionation. Geochim. Cosmochim. Acta 99, 18-38.

Yesavage T., Stinchcombb G. E., Fantle M. S., Sakd P. B., Kasznele A. and Brantley S. L. (2016) Investigation of a diabase-derived regolith profile from Pennsylvania: Mineralogy, chemistry and Fe isotope fractionation. Geoderma 273, 8397.

Zambardi T. and Poitrasson F. (2011) Precise Determination of silicon isotopes in silicate rock reference materials by MC-ICPMS. Geostand. Geoanal. Res. 35, 89-99.

Ziegler K., Chadwick O. A., Brzezinski M. A. and Kelly E. F. (2005) Natural variations of $\delta^{30} \mathrm{Si}$ ratios during progressive basalt weathering, Hawaiian Islands. Geochim. Cosmochim. Acta 69, 4597-4610.

Associate editor: Jan G. Wiederhold 